\title{
TAX ASSESSMENTS OF REAL PROPERTY: A PROPOSAL FOR LEGISLATIVE REFORM
}

The real property tax is the primary instrument ${ }^{1}$ and perennial whipping boy of municipal finance. ${ }^{2}$ Characteristically, it is a nongraduated levy on the

1. In 1955 , the most recent year for which statistics are available, general property taxes constituted over $85 \%$ of the income from all sources of units below the state level, and over $99 \%$ of their revenues from taxes. U.S. Census Bureau, Sumarary of GovernMental Finances in 1955, at 20 (1956). Federal property taxes are effectively barred by U.S. CoNsT. art. I, $\S 9, \mathrm{cl} .4$, and state property taxes have dwindled in importance. By 1957, 15 state governments had abandoned property taxation altogether and, in each of 17 of the remaining 33 states, such taxation yielded less than $\$ 5,000,000$. U.S. CENsus Bureau, Compendium of State Government Frnances in 1957, at 11 (1958). See generally Newcomer, The Decline of the General Property Tax, 6 NAT'L TAX J. 38, 45-46 (1953).

Property taxes account for about $94 \%$ of county and township tax revenues, almost $75 \%$ of city tax resources, $98 \%$ of school-district levies, and $100 \%$ of the tax collections by special districts. When nontax revenues-mainly from public utilities, alcoholic beverage sales, pension contributions and intergovernmental grants-are considered, property taxes yield over half the income of townships and school districts and over one third of aggregate county and city income. Self-supporting, publicly owned utilities account for the fact that property taxes contribute only about one sixth of special district receipts. U.S. Census Bureau, Summary of Government Finances in 1955, at 20 (1956). These relationships seem to prevail regardless of the size of the locality. A 1949 study of tax revenues in 18 large cities revealed that property taxes raised more than half the state and local revenue in 5 cities and between one half and one third in 11 others. Manning, Burdcn of Statc and Local Taxes in 18 Large Cities, 2 NAT'L TAX J. 173, 175 (1949).

In most states municipalities impose both real and personal property taxes, with the great bulk of property tax revenue clearly arising from the former. NationaL. INDUSTRIAL. Conference Board, Economic Alaranac 1951-52, at 511 (1951); Musgrave, Carroll, Cook \& Frane, Distribution of Tax Payments by Income Groups: A Case Study for 1948, 4 NAT'L TAX J. 1, 21-22 (1951). In some states, personalty is excluded from the property tax. See, $c . g .$, N.Y. Tax Law $\$ 3$ (effective Oct. 1, 1959, N.Y. REal Prop. Tax Law $\$ 300)$ (complete exclusion); Conn. Grn. Stat. \& 1050d (Supp. 1955) (exclusion of all nonbusiness personalty); N.H. Rev. Stat. ANN. $\$ 72: 15$ (1955) (exclusion of all intangibles). In other states, personalty is subject to assessment or taxation at lower rates than realty. See, c.g. Mont. Rev. Codes ANn. \$§ 84-301, -308 (Supp. 1957), 84-302 (1947) (fractional assessment); OHro Rev. Code Ans. \$§ 5707.03, 5711.22 (Page 1954) (preferential rates). And even in those states that purport to tax personalty fully, its underassessment is virtually universal. Newcomer, supra at 45-46. Compare IrL. AnN. Stat. ch. 120, § 499 (Smith-Hurd 1954) with Troupis, Full Fair Value Assessment in Illinois, 44 IrL. L. REv. 160, 178 (1949).

2. See S. REP. No. 1310, 84th Cong., 2d Sess. 12 (1956) (supplemental views of Senator Paul H. Douglas that property tax is regressive); Morton, Housing Taxation (1955) (similar) ; WASH. Rev. CODE ANN. § 84.41 .010 (Supp. 1957) (inequitable administration); N.J. Comm'n on State Tax Policy, The General Property Tax in New Jersey 25-29 (6th rep. 1953) (same); Shannon, Recent Statererde Programs to Improve Local Assessments, in 44 National Tax Ass'n, Proceedings 161, 166-67 (1951) (assessors' discretion results in usurpation of legislative functions). 
value of all taxable realty. ${ }^{3}$ Conceptually and functionally, it is the least satisfactory of American taxes. ${ }^{4}$ In contrast with the federal income tax-which exacts revenues according to ability to pay, supplements national economic policies, imposes a predictable liability on taxpayers, and operates with machinelike precision through wage withholding procedures ${ }^{6}$ - the real estate tax commonly falls most heavily on those least able to pay, embodies no clear policy ancillary to revenue raising, frustrates taxpayers who attempt to compute their own liability, and invites political manipulation by local administrators. Not surprisingly, therefore, the real property tax has stimulated various and vigorous criticisms directed at its inefficiencies and inequities. ${ }^{6}$

Most of the inequities are attributes of the assessment process, which consists of assigning a money value to individual realty parcels. ${ }^{7}$ Given the total assessed

3. See Lutz, General Property Tax, in 6 Encyclopedia of the Soctal Sciences 602 (1931).

4. For the absence of a rationale supporting the tax and for its administrative complexities, see 1 Bonbright, Valuation of Property 453-59, 480-99 (1937) [hereinafter cited as BonbrigHT]; Taylor, Economics of Public Finance 295-307 (rev. ed. 1953). In contrast, a properly designed sales tax is easy to administer, promotes increased investment and production, and relates tax level to consumption expenditures, arguably a superior index of ability to pay than income. Customs levies, while not progressive, have the acknowledged purpose of discouraging the importation of the taxed commodity. Even though most tariffs are ad valorem, specific statutory provisions eliminate most valuation problems. See 70 Stat. 943 (1956), 19 U.S.C. $\$ 1402$ (a) (Supp. V, 1958). Excises may be progressive, as are taxes on genuine luxuries, or regressive, like tobacco taxes. Most excises, such as liquor, tobacco and oleomargarine taxes, are sumptuary taxes, designed to discourage the consumption of the taxed articles. TAYLOR, THE Economics of Public Finance 240 (rev. ed. 1953). A major exception is the motor-vehicle fuel tax, which can be regarded as part of the price highway users pay for road construction and maintenance. Bowman \& Bach, Economic Analysis and Public Policy 725 (2d ed. 1949). The balance of the excises, such as the taxes on cabarets and automobiles, are wartime holdovers originally intended to absorb excess consumer demand or shift it away from scarce commodities. Hart \& Brown, Financing Defense 48-59 (1951). The few remaining federal taxes-on narcotics, occupational gambling and the like-are really federal regulatory devices.

5. See generally, Surrey, The Congress and the Tax Lobbyist-How Special Tax Provisions Get Enacted, 70 HARv. L. REv. 1145-55 (1957).

6. See note 2 supra.

7. Assessment is a three-step process consisting of discovery of property to be taxed, valuation, and review. See generally National Ass'n of Assessing Officers, Assessment Princtples and Terminologi (1937); 1 Bonbright 480-92.

As used in this Comment, "assessment" will ordinarily refer to valuation.

The discovery of realty long consisted of supplementing the prior year's tax roll with new improvements shown on a "list" required to be filed annually by taxpayers, and with those turned up by the more or less casual observations of the local assessor. Under this system, both land and improvements often escaped assessment. NATIONAL Ass's of Assessing Officers, Construction and Use of Tax Maps 5-8 (1937). More modern practice dispenses with taxpayers' lists and relies on surveys, maps, and aerial photography and building-permit records. See, e.g., ConN. GEN. STat. § 1037d (Supp. 1955); WASH. Rev. Cone ANx. \$§ 36.21.050-.080 (Supp. 1957).

Valuation is the second step in assessment. New improvements have customarily been valued by acceptance of the owner's "listed" value. The infrequent revisions of "listed" 
value of all parcels, municipalities, school districts, and other spending authorities can determine what percentage of that value should be set as the applicable tax rate in order to produce desired revenues. ${ }^{8}$ The local officials who are responsible for making assessments often occupy positions of unique autonomy, partlybecause they may enjoy political independence from local spending authorities, ${ }^{9}$ and partly because they invariably function under imprecise state legislation which leaves them free to devise their own valuation standards. ${ }^{10}$ As

values have reflected guesswork on the part of the assessor or community. Once established, these values, diminished in conformity with the assessor's idea of a proper ratio of assessed to computed value, have been copied onto each succeeding year's tax roll. 1 Bonbright 486-87; Taylor, op. cit. supra note 4, at 295-301. Dissatisfaction with this practice accounts for the provision in many statutes requiring the assessor personally to view each parcel annually. See, e.g., N.M. STAt. Ann. \$ 72-2-10.2 (Supp. 1957). Compare Conn. Gen. Stat. § 1064d (Supp. 1955) (realty must be viewed during decennial revaluations); TeNN. CoDE ANN. $\$ \$ 67-601,-626$ (1956) (biennially). The multitude of parcels, even in smaller municipalities, makes an annual viewing impractical. See Switz v. Middletown, 23 N.J. 580, 598-99, 130 A.2d 15, 25 (1957) ; Haig \& Shoup, The Financial Problem of the City of New York 143 (1952). Development of mass appraisal techniques based on building costs has improved original assessments, but roll copying is still common. Many statutes require revaluation only at intervals of up to ten years, and evidence exists that even these requirements are not complied with. See, e.g., Cons. Gen. Stat. \$ 1046d (Supp. 1955) (extending ten-year period to fifteen); N.C. Gen. Stat. ANN. \$ 105-278 (1958) (extending time for completion of quadrennial revaluation).

In many jurisdictions, local review boards oversee local assessors and state review boards hear appeals from local boards. In some cases, these review boards consist of county supervisors or state officers overseeing assessments in ex officio capacity. In other cases, full time is devoted to tax duties. National atss' $N$ of Assessing OfFicERs, AssessMIENT SUPERUISION (7th Progress Rep. 1940). Universally, state courts are open to taxpayers either after or in lien of recourse to review boards. Absent a state remedy for the unequal treatment of taxpayers, federal courts may have jurisdiction under the fourteenth amendment. See note 22 infra.

8. The preparation of a budget by the local executive proceeds concurrently with the assessor's preparation of the "grand list" of realty assessments. The degree of coordination and the direction of flow of influence between spending and assessing authorities depends on local political conditions. The complete budget document shows contemplated total spending and estimated non-realty-tax revenue. The realty tax rate is determined by dividing the difference between these figures by the "grand list" total. The adoption of the tax rate by a local legislative body is, technically, the levy, though usage has extended the term to cover the entire process. Buck, Munictpal Bungets and Budget Makrnag $39-60$ (1925).

In many communities, tax-rate limits are so low that maximum levies are inescapable. Total revenue can be increased only by increasing other taxes or by raising assessments. See notes 13, 14, 26, 28 infra.

9. Assessors may be elected, locally appointed, or selected on higher governmental levels. Natronal Ass'n of Assessing Officers, Selection, Tenure, and Compensatron "F Assessons (1940). While an elected assessor will ordinarily be a member of the local pulitical "team," he need not necessarily be. An appointed assessor may be politically independent as the result of strict merit selection, or of a political difference between those who govern the locality and those who appoint the assessor.

10. "Fair value," "true value" and "market value" are typical legislative assessment standards. Assessors are commonly directed to seek the price that property would command 
a result, assessors can frequently manipulate their valuations to favor individual taxpayers, ${ }^{11}$ to reduce the local incidence of state and county realty taxes, ${ }^{12}$ to govern the revenue-raising power of municipalities, ${ }^{13}$ and to subvert state grant-in-aid requirements expressed in terms of local assessed valuations. ${ }^{14}$

Past legislative tinkering with realty taxation has generally produced measures which fall short of adequate reform. For example, tax exemptions favoring farmers, veterans, and homeowners have partially compensated for the tax's regressivity, ${ }^{15}$ that is, its tendency to take greater proportions of income from

in a voluntary arm's-length sale. The assessor's attention is often directed to various factors, including original or replacement cost, book value and income or earning capacity, but these factors are never assigned specific statutory weights. For a summary of the value provisions of all states, see appendix at p. 386 infra.

11. See text at notes 110-12 infra.

12. Such manipulation is possible in the not uncommon situation in which a single realty parcel lies within two or more taxing jurisdictions. To avoid duplication of effort, the assessed valuations of one jurisdiction-usually the town or county-are ordinarily adopted by all taxing jurisdictions. If a levying district covers more than one assessing district and levies are at a uniform rate, a local assessor can ensure that his constituents will pay less than their share of taxes to the overlapping district by assessing property in his community at lower levels than do neighboring assessors. See 1 BonBrigrt 503-04; Weil, Property Tax Equalization in Illinois, 6 NaT' $\mathrm{T}$ TAX J. 157, 165-66 (1953) (citing examples). In addition to the counties, cities, towns and villages, some 65,000 independent, special-purpose taxing districts exist to supply schools, sewers, water, fire protection and similar services. If the state itself utilizes a realty tax, an additional level is added to the structure. Hansen \& Perloff, State and Local Finance 82-90 (1944).

13. The taxing and borrowing powers on the local level are each frequently limited to a given percentage of assessment valuation. See, e.g., CoNN. GEN. Srat. \$\$ $\$ 07$ (1949), 363d (Supp. 1955) (debt limit); Kan. Gen. Stat. ANN. \$§ 1905, 1946-62a (Supp. 1957) (tax limits classified by purpose, size of levying unit and size of grand list) ; N.Y. LoCAL Frn. Law § 104 (debt limit); OHIo Rev. Code ANN. \$ 5705.02 (Page 1953) (ten-mill tax limit). See generally Property Tax Limitation Laws (Leet \& Paige ed., Public Administration Service Pub. No. 36, 1934); Morris, Evading Debt Limitations With Public Building Authorities: The Costly Subversion of State Constitutions, 68 YaLE L.J. 234, 240-43 (1958). Where legal ceilings are lacking, limits not infrequently are imposed by political realities. Whatever their source, when limits are reached the assessor can, by varying assessments, produce corresponding changes in permissible municipal spending and borrowing.

14. State grants-in-aid are commonly contingent on municipal expenditures for the aided activity equal to a certain percentage of the municipality's total assessed property valuation. See, e.g., Iow Code ANN. \$\$ 286.4, 286A.1 (Supp. 1958) (local fifteen-mill school tax prerequisite to state education aid); OKLA. Stat. ANN. tit. 70, $\$ 18-4$ (Supp. 1958) (same). Where grants are conditioned on the expenditure of proportions of assessed value rather than on total local expenditures, reduced assessments enable local communities to receive state funds for lower corresponding amounts of local funds. See Troupis, Full Fair Value Assessment in Illinois, 44 ILI. L. Rev. 160, 165 (1949); of. Davies, The Louisiana Property Tax Relief Fund: A Source of Financial Assistance for Local Govermments, 1 NAT'L TAX J. 270, 271 (1948) (assessor manipulation to maximize state reimbursement for revenue lost through exemptions).

15. See notes 113-14, 128-30 and accompanying text infra.

Any flat rate deduction from taxable amount makes a tax more progressive. Thus, a $\$ 1,000$ exemption would make the effective rate of a $4 \%$ tax on a $\$ 5,000$ assessment $3.2 \%$, 
lower than higher income groups. ${ }^{10}$ Since such exemptions provide irresponsible legislators a means of distributing state gratuities by diminishing local revenues, ${ }^{17}$ exemption provisions frequently assume pork-barrel dimensions and thereby generate new inequities. ${ }^{18}$ More ambitiously, many states have attempted to prevent the manipulation of assessment levels and to eliminate needless discrimination within assessing districts. Hence that well-intended commonplace-the statutory or constitutional requirement that every assessment be made at a uniform proportion of the realty's "full value."19 Despite adjurations of this sort, local assessors habitually disregard the prescribed proportion of "full value" and assign lower values to most property. ${ }^{20}$ Since courts are rarely willing to order the costly and time-consuming general revaluations necessary to correct what has become chronic underassessment, the judicial maintenance of proper levels of assessed values is substantially foreclosed. ${ }^{21}$ In fact, the judiciary has helped perpetuate underassessment by single-mindedly

on a $\$ 10,000$ assessment $3.6 \%$, and on a $\$ 20,000$ assessment $3.8 \%$. See generally, BLUM \& Kalven, The Uneasy Case for Progressive Taxation 3-4 (1953). 1949).

16. See Bowman \& Bach, Economic Analysis and Public Policy 711 (2d ed. This

ment assumes that regressivity is an undesirable feature in a tax. For commentators taking this view, see BIUM \& KALVEN, op. cit. supra note 15; Surrey, The Congress and the Tax Lobbyist-How Special Tax Provisions Get Enacted, 70 Harv. L. REv. 1145 (1957). For a contrary view, see Tucker, Distribution of Tax Burdens in 194S, 4 Nır'L TAX J. 269, 278 (1951).

17. See Spears, Veterans' Property Tax Exemptions, 11 NaT'L TAX J. 129, 136 (1958). By reimbursing localities for revenue lost through exemptions, some states have assumed responsibility for legislative exemptions. See, e.g., LA. Const. art. 10, $\S \S 4(9)$, 4(9) (a), 4(9) (b).

18. Newcomer, The Growth of Property Tax Exemptions, 6 NaT'L Tax J. 116 (1953) ; Davies, The Loutsiana Property Tax Relief Fund: A Source of Financial Assistance for Local Governments, 1 NAT'L TAX J. 270 (1948). Compare S. REP. No. 1310, 84th Cong., 2d Sess. 14 (1956) (criticisms of injustices involved in federal tax exemptions and preferences); Surrey, supra note 16 (same).

19. For states requiring that assessments be at "full value" or similarly termed levels, see appendix at p. 386 infra.

Uniform assessments may be specifically required. See, e.g., IND. STAT. ANN. § 64-103 (1951); Texas Consr. art. $8, \$ 1$. Alternatively, particular discriminations may be proscribed. See, e.g., Ala. CoNst. art. 11, $\$ 217$ (requiring uniform treatment of "private corporations, associations, and individuals"); CAL. Const. art. 13, $\$ 2$ (Cultivated and uncultivated land"); Conn. Public Acts 1957, No. 673, \$§ 6, 7, at 1090 (real and personal property). Other states require uniformity only within reasonable classifications. See, e.g., ArIz. Const. art. 9, $\S 1$ ("taxes shall be uniform upon the same class of property"); FLA. Const. art. 9, § 1 ("uniform and equal" except intangibles at lower rate); MoNr. Rev. CODEs ANn. § 84-301 (Supp. 1957) (seven property classes, three containing realty, assessed at from 7 to $100 \%$ ).

20. See text at notes 26-28 infra. For a discussion of the judicial dilemma posed by undervaluation, see E. Ingraham Co. v. Bristol, 144 Conn. 374, 381-83, 132 A.2d 563, 566-67 (1957).

21. For a statement of the costs involved in a partial revaluation undertaken under threat of mandamus, see Hammermill Paper Co. v. City of Erie, 372 Pa. 85, 88, 92 A.2d 422,425 (1952). The complexity of a comprehensive reassessment of an entire township 
enforcing the requirements that property values be uniform. ${ }^{22}$ Litigating taxpayers have accordingly been able to reduce their assessments to the prevailing, administratively created proportion of "full value," while nonlitigating taxpayers have been left to the assessor's mercy-and measure of value.

Another prevalent reform is designed to eliminate the uneven treatment of taxpayers in different assessing districts. To this end, legislatures have created county- and state-wide equalization boards, and have authorized them to adjust general, interdistrict assessnent levels. ${ }^{23}$ These provisions, like those decreeing uniformity and granting exemptions, have had dubious success. The activities of these boards have been at best sporadic, ${ }^{24}$ and equalization techniques have

led the New Jersey Supreme Court to approve a three-year stay of an order to that effect in Switz v. Middletown, 23 N.J. 580, 597-99, 130 A.2d 15, 24-25 (1957). See also Note, 46 HARv. L. REv. 1000 (1933).

Statutes in several states authorize central administrators to order reassessments on petition by aggrieved taxpayers. See, e.g., Wis. Stat. $§ 70.75$ (1955) ; N.H. Rev. Stat. Ann. $\$ \$ 71: 12,71: 13$ (1955) ; Neb. Rev. Stat. Ann. $\$ \$ 77-307$ to -310 (1943). In Wisconsin these provisions are frequently invoked. Letter from Wisconsin Commissioner of Taxation to the Yale Laze Journal, Sept. 16, 1958, on file in Yale Law Library. In New Hampshire, they were used twice from 1946 through 1958. Letter from Secretary of New Hampshire Tax Commission to the Yale Law Journal, Sept. 12, 1958, on file in Yale Law Library. In Nebraska, they have never been employed. Letter from Assistant Tax Commissioner of Nebraska to the Yale Law Journal, May 12, 1958, on file in Yale Law Library. See also National Ass's of Assessing Officers, Assessment Supervision 20-25 (7th Progress Rep. 1940). Since tax commission orders affecting particular properties are generally reviewable, a refusal to grant a requested reassessment authorized by statute could probably be judicially reviewed. Cf. Hill v. Marvin, 98 N.H. 519, 104 A.2d 200 (1954) (reviewing issuance of reassessment order).

22. See, e.g., McCluskey v. Sparks, 80 Ariz. 15, 291 P.2d 791 (1955) ; People $e x$ rel. Wangelin v. Wiggins Ferry Co., 357 I11. 173, 180-81, 191 N.E. 296, 299 (1934) ; Appeal of Matson, 152 Pa. Super. 424, 33 A.2d 464 (1943). See also 1 BongRIGHT 500-03; Note, Remedies for Unequal Property Tax Assessment, 46 Harv. L. Rev. 1000 (1933).

Failure to grant relief when lack of uniformity is sufficiently gross to support a presumption of deliberate discrimination, violates the equal protection clause of the fourteenth amendment and, absent a state remedy, is correctable in federal court. Sioux City Bridge Co. v. Dakota County, 260 U.S. 441 (1923); Keokuk \& Hamilton Bridge Co. v. Salm, 258 U.S. 122 (1922) (dictum).

23. Lee, State Equalization of Local Assessments, 6 NAT'L TAX J. 176 (1953). Typically, the equalization process calls for the computation of an assessment ratio based on comparisons of either actual sales or independent appraisals of selected properties. See Weil, Property Tax Equalization in Illinois, 6 Nat'l TAx J. 157 (1953); Welch Intercounty Equalization in California, 10 NAT' TAX J. 57, 148 (1957). This ratio may be used to adjust assessment totals upon which allocations of state aid are based, or to compute statutory debt and tax limits. See, e.g., N.Y. Educ. LAw $\$ 3602$ (state aid); N.Y. Const. art. 8, $\$ \$ 4,10$ (debt limits); N.Y. LoCAL FIN. LAw $\$ 2(7-a)$ (tax limits). The ratio may also be the basis for an across-the-board adjustment of individual assessments in a given assessing or equalizing district. See, e.g., N.J. STAT. ANs. $\$ \$$ 54:3-16, 54:3-19, 54:4-49 (Supp. 1957) (county equalization) ; KY. Rev. Stat. $\$ \$ 133.170,133.180,133.185$ (1953) (state equalization).

24. Nationat Ass'n of Assessing Officers, Equalization Agencies 34-37 (6th Progress Rep. 1940); Shannon, The Conflict Between Law and Administrative Practice in Valuation of Property For Taxation in Kentucky passizn (1957). But see examples of active equalization programs cited note 23 supra. 
sometimes aggravated individual discrepancies in the process of redressing overall imbalances. ${ }^{25}$

Attempted reforms seeking to control spending by municipalities have also had unfortunate effects on the property-assessment process. Specifically, the legislative prescription of maximum local tax rates and debt limits enables assessors to determine the level of municipal revenues and expenditures. ${ }^{26} \mathrm{Limitations}$ on permissible tax rates manifestly do not restrict assessors in the exercise of their discretion; and, in practice, assessors often defeat a legislature's intended fiscal controls by varying the ratio of assessed to market values. ${ }^{27}$ Thus, tax-rate limits merely shift the locus of authority over revenue levels from the elected officials who set tax rates to the supposedly non-policy-making assessors and the judges who occasionally review assessments. ${ }^{28}$

The many objectionable features of realty taxation have encouraged the enactment of municipal sales ${ }^{29}$ and income taxes, ${ }^{30}$ but these alternative sources

25. To the extent that equalization affects assessments, they ordinarily are raised uniformly. Tax rates rarely are reduced commensurately, since communities generally have large spending demands which keep tax rates at the maximum levels allowed by statute or popular consent. When assessment rates are raised and tax rates are not changed, the ratio between any two individuals' tax bills will remain constant, but the increase imposed on the relatively overassessed taxpayer will be absolutely and proportionally greater. The table below shows the possible results when individual assessments in an underassessed community are uniformly doubled to bring the average assessment level from $50 \%$ to $100 \%$ of computed value.

\begin{tabular}{lrrrr} 
& \multicolumn{2}{c}{ Before equalization } & \multicolumn{2}{c}{ After equalization } \\
& Taxpayer & Taxpayer & Taxpayer & Taxpayer \\
& $A$ & $B$ & $A$ & $B$ \\
\hline Computed value & $\$ 10,000$ & $\$ 10,000$ & $\$ 10,000$ & $\$ 10,000$ \\
Assessment & $\$ 7,500$ & $\$ 2,500$ & $\$ 15,000$ & $\$ 5,000$ \\
Individual assessment ratio & $75 \%$ & $25 \%$ & $150 \%$ & $50 \%$ \\
Tax at 4\% rate & $\$ 300$ & $\$ 100$ & $\$ 600$ & $\$ 200$ \\
Cost of equalization & & & $\$ 300$ & $\$ 100$ \\
\hline
\end{tabular}

But see Seannon, op. cit. supra note 24, at 43-44 (assuming offsetting decreases in tax rates).

26. See note 14 supra. For a discussion of the purposes and effects of tax-rate limitations, see Jensen, Property Taxation in the United States 468-69 (1931); Newcomer, The Decline of the General Property Tax, 6 NaT'L TAX J. 38 (1953); Thompson, Effects of Property Tax Limitations in West Virginia, 4 NAT'L TAX J. 129 (1951).

27. Shannon, op. cit. supra note 24 , at $3,65,102-08$.

28. A not dissimilar shift of authority occurs whenever a legislature customarily revises municipal tax-rate limits or provides alternative revenue sources on the petition of municipalities. New York City, for instance, is dependent on the continued state authorization of sales taxation and on new, state-authorized revenue sources to supplement the statutorily limited realty tax. The annual struggle and compromise between state legislators and city officials over city spending levels is notorious. See, e.g., N.Y. Times, April 20, 1954, p. 1, col. 2; id., March 4, 1954, p. 1, col. 2; id. March 22, 1954, p. 18, col. 1 .

29. Pioneered by New York City, local sales taxation has spread to four other cities and three counties in New York State. In California and Illinois, 313 and 919 municipalities, respectively, including Los Angeles, San Francisco and Chicago, employ sales taxation. Forty-six communities in Mississippi have sales taxes, as does Washington, D.C., and scattered cities in Alabama, Arizona, Colorado, Louisiana, New Mexico, and Vir- 
of revenue do not permit communities to remain fiscally independent in setting their tax rates. Only so long as sales taxes are low will neighboring communities be likely to adopt different rates; as rates and differentials increase, sales taxation affects commerce adversely in high-rate localities. ${ }^{31}$ As for municipal income taxes, rate differentials are administratively burdensome unless the employers of persons who live and work in different communities can allocate all withheld taxes to one jurisdiction. ${ }^{32}$ Finally, both local income and sales taxes

ginia. Rates range from a high of $3 \%$ in New York City to a low of $1 / 2 \%$ in the states of Illinois and Mississippi and in Phoenix, Arizona. Due, Sales Taxatron 317 (1957). See also Glander, New Types of Nunicipal Non-Property Tax Revenues, 3 Nat' Tax J. 97 (1950).

30. Seventeen cities and 396 boroughs, school districts and townships levy such taxes in Pennsylvania. Sixteen Ohio cities employ the tax, as do St. Louis and four Kentucky municipalities-Louisville, Paducah, Lexington and Newport. Washington, D.C., imposes an income tax modeled after the federal one, but this municipality is generally classed as a state rather than a city in fiscal discussions. New York City has unused authority to impose an income tax. Sigafoos, The Municipal Incone TAx 1-11, 76 (1955).

Tax rates range from $1 \mathrm{I} / 4 \%$ in Philadelphia to $1 / 8 \%$ in Williamsport, $\mathrm{Pa}$. Rates are ungraduated in all jurisdictions. Personal exemption provisions are rare, with only two Ohio cities granting them. Ibid. Except in Ohio, where a unique "pre-emption" doctrine gives localities the power to impose any tax not used by the state, Angell v. City of Toledo, 153 Ohio St. 179, 91 N.E.2d 250 (1950), income tax authority is conferred by state statute, Ky. Rev. Stat. § 91.200(1) (1953); Mo. Ann. Stat. \$ 92.110 (Supp. 1958); Pa. Stat. ANN. tit. $53 \S 8851,15971$ (1957).

31. See Due, Sales Taxation 316-20, 324 (1957). Compare Haig \& Shoup, The Saies Tax in the American States 475-86 (1934).

To discourage local residents from shopping in neighboring towns which do not impose sales taxes, cities exacting such taxes have commonly imposed use taxes on major out-oftown purchases by residents. To allow local merchants to attract out-of-town shoppers, purchases of nonresidents delivered out of town are exempted from the sales tax. E.g., New York City AdMinistrative Code $\S \S$ M41-15.0 to -17.0 (1956). Difficulties of enforcement limit the effectiveness of use taxes and nonresident exemption to sales of major items. See Due, Sales Taxation 308-09 (1957) ; Haig \& Shoup, The Financial ProbLEMI OF THE CITY of NEW YORK 204-06, 207-11 (1952). California, on the other hand, has devised a system by which rates and rules are standardized among localities; however, the system sacrifices local control and, in effect, coerces cities to adopt sales taxation whether needed or not. Due, Sales Taxation 320-23 (1957).

32. Most municipalities tax income earned elsewhere by their own residents, as well as the local earnings of nonresidents. Qunito, Municipal Income Taxation in the United States 14, 44, 77-78 (Mayor's Comm. on Management Survey, Technical Mínograph No. 2, 1952). If an employer is asked to withhold varying amounts for a multiplicity of tax collectors, his bookkeeping requirements become oppressive. Since cities generally lack the power to require a nonresident firm to withhold taxes, such an employer may minimize his accounting complexities by refusing to withhold the tax. Tax evasion by employees is thus abetted. Sigafoos, The Municrpal Income $T_{A}$ 42-45 (1955).

Two approaches to the employer's accounting problems have been developed. Pennsylvania assigns half of the $1 \%$ maximum rate to each of two competing jurisdictions. This tends to produce uniform $1 / 2 \%$ tax rates. Where a central city imposes an income tax at the maximum rate allowed by statute, surrounding commuter towns can, by adopting their own income tax, capture substantial revenues at no extra cost to most voters. But this uniformity is achieved only by encouraging suburban areas to expand their spending unrealistically, and by defeating the income tax's function of allowing central cities to shift some costs of government to daytime residents. Dissatisfaction with these arrange- 
may be steeply regressive. The former are collected primarily from business profits and withheld wages, but not from investment returns, nonbusiness capital transactions, or self-employment earnings. ${ }^{33}$ For their part, sales taxes fall most heavily on low-income families, who spend proportionately more for taxed goods and less for untaxed services and savings than do higher-bracket groups. ${ }^{34}$

The absence of an entirely satisfactory substitute for realty taxation compels the acceptance of arguments for its retention. Realty's fixed situs and locally recorded ownership make the tax easy to administer $;^{35}$ the inability of local taxing units to gain sufficient revenues from income and sales taxes demonstrates the fiscal necessity of taxing real property. ${ }^{36}$ In any event, the limited voting

ments has led some central cities and neighboring towns to share revenues on other than the statutory fifty-fifty basis. The necessity of negotiating sharing arrangements with other jurisdictions limits local fiscal independence, but results in a more realistic allocation of revenue between the central city and the suburbs. On the other hand, by eliminating uniform rates, sharing reintroduces burdensome employer calculations. By establishing a joint tax collector, however, cooperating localities can ease the employer's accounting problems, for employers are then faced with only one tax rate and one collecting authority. See id. at 27-30, 49-51. The second or Ohio approach-giving the place of employment absolute priority-encounters difficulties similar to those obtaining in Pennsylvania. See id. at 30 .

33. Sigafoos, The Municipal Income Tax 19-22 (1955).

34. Bowman \& Bach, Economic Analysis and Public Policy 727 (2d ed. 1949); Taylor, The Economics of Public Finance 412 (rev. ed. 1953). Exempting food and other necessities may partially offset this tendency. See McGrew, Effect of a Food Exemption on the Incidence of a Retail Sales Tax, 2 NAT'L TAX J. 362 (1949).

35. See Macy, Some Legal and Administrative Aspects of The Property Tax in Oregon, 33 Ore. L. Rev. 180-81 (1954). Compare New Jersey Conmr'n on State TaX Policy, Tae General Property Tax in New Jersey at xxv (6th Rep., 1953) (arguing that realty tax burden is lower than burdens of alternative taxes).

36. Even in municipalities which rely heavily on sales or income taxation, property taxes continue to play a significant role.

\begin{tabular}{lrrr}
\hline \hline Sales Tax Cities & $\begin{array}{c}\text { Total Tax } \\
\text { Revenues }\end{array}$ & $\begin{array}{c}\text { Sales Tax } \\
\text { Revenues }\end{array}$ & $\begin{array}{c}\text { Property Tax } \\
\text { Revenues }\end{array}$ \\
\cline { 2 - 4 } & \multicolumn{3}{c}{ (in thousands of dollars) } \\
\hline New York City & $\$ 1,249,595$ & $\$ 345,705$ & $\$ 819,884$ \\
Los Angeles & 104,377 & 29,033 & 59,595 \\
Chicago & 209,469 & 22,145 & 117,129 \\
New Orleans & 26,363 & 8,037 & 12,473 \\
\hline
\end{tabular}

*Overstated; includes gross receipts tax.

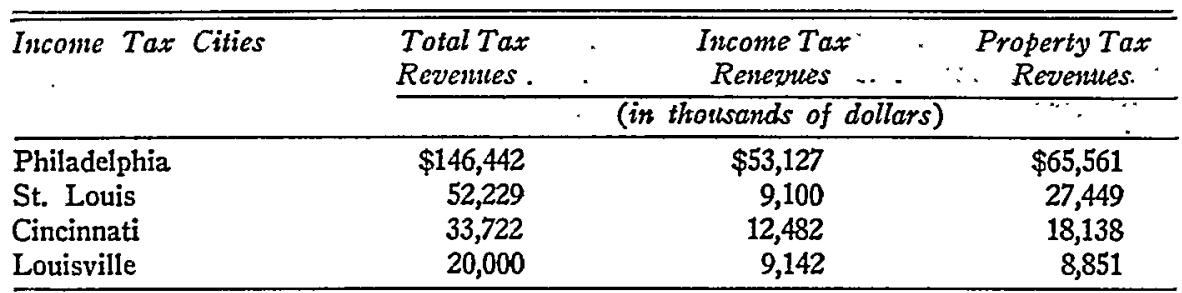

Source: U.S. Census Bureau, Compendum of City Government Finances in 1956, at 27, 37 (1957).

Compare Royal Institute of Public Administration, New Sources of Local Revenue 
power of urban property owners makes continued use of the tax almost certain. Since the real property tax is, therefore, apparently destined to survive its critics, means should be sought to eliminate its most grievous faults-its regressivity and unpredictability, and the political manipulation of assessed values.

\section{Traditional Policies and Technigues in Realty Taxatron}

The seeds of realty tax reform are embedded in current assessment policies and procedures, which have necessarily developed independently of such vague definitions of taxable amount as "full value" and its variants-"cash value," "true value," "actual value," and "fair value." 37 Assessors and courts, uncertain as to the measurement systems and tax-distribution policies which these terms obscure, have relied on their own ingenuity in implementing the statutory standards. Whatever order and purpose the tax reflects must therefore be attributed largely to adjudication and administration, not to legislation.

\section{"Value" Under Different Computation Systems}

The techniques by which assessors and courts currently translate abstract legislative statements of value into dollar amounts are the three standard methods developed by professional appraisers and economists for other purposes. $^{38}$ The market-comparison approach utilizes the actual sales prices of realty parcels comparable to the one being appraised. ${ }^{39}$ Alternatively, depreciated reproduction cost measures present value by subtracting total depreciation from the hypothetical current cost of reproducing the improvements in question..$^{40} \mathrm{Or}$, thirdly, realty can be valued by capitalizing anticipated

13-16 (1956) (property taxes must remain the primary though not sole source of local revenue).

37. For the jurisdictions employing these terms, see appendix at p. 386 infra.

38. See Wendt, Real Estate Appraisal 1-140 (1956) [hereinafter cited as WendT]; 1 BONBRIGHT 113-34.

39. See generally Wendt 253-92; Weimer \& Hoyt, Princtples of Real Estate 26063 (3d ed. 1954) [hereinafter cited as WeIMER \& HoYT]; 1 Bonbright 127-39.

40. See Wendr 212-52; WeIMER \& Hoyt 262-69; 1 BonBright 140-215. Unlike the other two approaches, depreciated reproduction cost measures the value of improvements only. The theory of depreciated reproduction cost is that buyers would be willing to pay as much as, and sellers unwilling to accept less than, the cost of replacement. In practice, appraisers usually estimate the current cost of constructing the improvement anew and then deduct the value lost by age. A variant method is to subtract depreciation from the original cost and adjust for price level changes. See Town of Kearny v. Division of Tax Appeals, 137 N.J.L. 634, 61:A.2d 208 (Sup. Ct. 1948), aff'd, 1 N.J. 409, 64 A.2d 67 (1948).

Style changes which affect costs present vexing problems. Ignoring style changes may result in predicting appraisals on costs of reconstructing improvements which, if destroyed, would not be replaced. On the other hand, calculating replacement cost in terms of structures conforming to present standards might produce a valuation far in excess of the utility of the building being valued. To some degree, allowances for obsolescence avoid this difficulty by adjusting for style changes to the extent that utility is reduced. 
future income. ${ }^{41}$ Under utopian, purely competitive market conditions, these methods would always produce identical answers. ${ }^{42}$ Frictions and imperfections characterize the real market, however, so that the different valuation methods can rarely be interchanged without affecting the result. Further, these methods are not equally sensitive to fuctuations in consumer taste and general business conditions. ${ }^{43}$ Finally, a particular method may become largely a matter of speculation because sales data are unavailable, or construction or rental figures are incomplete.44

Even when a single method is applied to a given parcel at a given time, several values may be found, for appraisals rest on commercial and economic assumptions which can vary because they are not susceptible of empirical proof. For example, the determination of depreciated reproduction cost involves

41. Income capitalization bases value on the present worth of future earnings. Income currently attributable to the property is computed, projected into the future, and then discounted in accordance with the interest rate for investments entailing similar risks. Noncommercial property can be valued under this system by imputing to it rents earned by comparable realty. See generally WeNDT 141-211; WeIMrer \& HoYT 255-60; 1 BoNBRIGHT 216-32.

42. A change in either construction costs, sales prices or income-producing ability theoretically produces corresponding changes in the other two. Buyers treat construction as an alternative to purchase; therefore, if market prices rise above reproduction costs, sales should drop and construction should increase. The price of existing structures would then decline and construction costs rise until equilibrium was re-established. Similarly, if extraordinarily large returns are produced by a class of property, investors will shift investments from other classes of property to the more profitable class. The increased buying of the profitable property will force up its price, while investors liquidating less profitable holdings will drive prices down on other property. This process will continue until equality of effective yield is restored. If the ability to produce and dispose of property freely is assumed, examples can be multiplied to demonstrate unvarying uniformity. See People $c x$ rel. Parklin Operating Corp. v. Miller, 287 N.Y. 126, 129-30, 38 N.E.2d 465, 467 (1941) ; Harvey, Valuation of Mortgage Security, 1957 U. IIL. L.F. 412, 416. But see Harvey, Observations on the Cost Approach, 21 Apprarsal J. 514 n.3 (1953) (harmony of reproduction-cost approach with capitalized-income and market approaches fudged through use of obsolescence allowances).

43. Thus the technological changes that made multistoried factories obsolete did not reduce their cost of reproduction. Despite their obsolescence, such structures may earn substantial returns for owner-occupants, but the price that they command on the market is substantially less than that of modern buildings. Similarly, the coming of television did not make motion-picture theater construction cheaper, but the decline in the industry was mirrored by a decline in theater sales prices and earnings. Compare B. F. Keith Columbus Co. v. Board of Revision, 148 Ohio St. 253, 74 N.E.2d 359 (1947).

44. Sales data are uncommon for property specially constructed for a particular business purpose. In some areas, farms are so rarely sold outside the family that market prices are totally unavailable. See Luce, Assessment of Real Property for Taxation, 35 Mrcm. L. Kev. 1217, 1222, 1226 (1937). In highly developed areas, sales of vacant land may be virtually nonexistent. See Pitney v. Kelly, 21 N.J. Misc. 405, 34 A.2d 547 (B.T.A. 1943). In markets dominated by owner occupancy, actual rental figures for use in capitalizing income are lacking. Thus assessments for British local taxes based on net annual rents present much the same problems as American fee valuation. See generally Ryde, Rating 241-630 (10th ed. 1956). 
such conjectural factors as a building's remaining life, and its rate of decline in worth from its cost of construction to its scrap value. ${ }^{45}$ Hence, an assumption about speculative elements of this sort ultimately controls the precise dollar value assigned to total depreciation. Similarly, the market-comparison test is based on assumptions concerning the relevance of sales data ${ }^{46}$ and income capitalization is, essentially, an assumption as to future earnings and interest rates. ${ }^{47}$

The appraisal technique chosen and the appraiser's underlying assumptions generally reflect the purpose for which value is being computed. ${ }^{48}$ The entrepreneur ordinarily establishes a building's worth by estimating expected profits from renting or using the structure. ${ }^{49}$ The insurer against destruction commonly views the cost of replacement as the proper measure.50 And the real estate broker doubtless assigns values in accordance with immediate sales possibilities. Lenders may consider all three approaches, but their desire for security will of course govern their commercial and economic assumptions. Thus, the income that a lender capitalizes will be the minimum income reasonably foreseeable during the life of the loan; his estimate of reproduction cost will emphasize the value lost and likely to be lost through age and changes in the arts; and his comparative sales analysis will be in the context of foreclosure sales. ${ }^{\text {t1 }}$

45. Appraisers establish depreciation either on the basis of "testimony of competent valuation engineers who examined the property and made estimates in respect of its condition" or on "mere calculations made on averages and assumed probability." MAX, THE Valuation of Residential Real Estate 145-57 (1956). (Emphasis added.)

46. Assumptions must be made concerning which features of realty affect sales prices. See, e.g., People ex rel. Johnson v. Robison, 406 Ill. 280, 284, 94 N.E.2d 151, 15354 (1950) (other lot prices rejected for terrain differences). When market conditions differ or when sales prices are affected by special, nonmonetary considerations, appraisers may differ as to which sales of physically comparable property are relevant to taxable value. Laflin v. State Bd. of Equalization, 156 Neb. 427, 56 N.W.2d 469 (1953) (twentyyear average used to eliminate peaks and troughs of market and atypical transactions); L. Bamberger \& Co. v. Division of Tax Appeals, 136 N.J.L. 463, 466, 57 A.2d 242 (Sup. Ct. 1948), aff'd on other grounds, 1 N.J. 151, 62 A.2d 389 (1949) (sale and lease-back transaction not evidence of market price); Pitney v. Kelly, 21 N.J. Misc. 405, 34 A.2d 547 (B.T.A. 1943) (neither sales of trackside land by railroad to heavy shipper nor tax sale by city relevant).

47. The appraiser must estimate not only the future income of the property being valued but also the rate of interest that would have to be paid to induce investment in the property. One recent writer has commented that "the concepts and techniques employed differ so widely that it appears that a capitalization rate must be conjured out of the appraiser's head." WENDT 162. For an example of the confusion caused by such speculation, see City of Newark v. Newark \& Essex Bldg. Corp., 25 N.J. Misc. 228, 52 A.2d 541 (Div. Tax App. 1947) (four experts, three capitalization rates).

48. See 1 Bonbright 4-5; Babcock, Valuation of Real Estate 159-64 (1st ed. 1932).

49. See Seagram's Bet on Elegance, Architectural Forum, July 1958, p. 76.

50. See Rodda, Fire and Property Insurance 107 (1956).

51. See Harvey, Valuation of Mortgage Security, 1957 U. ILL. L.F. 412. 
Courts and assessors choosing among diverse approaches and assumptions in order to distribute tax burdens equitably receive no greater statutory guidance than that value should be computed as at a private, arm's-length-rather than a foreclosure or auction-sale. ${ }^{52}$ True, some statutes, by referring to market value, cost price, earnings and depreciated reproduction cost, enunciate obscure criteria for selecting appraisal techniques. ${ }^{53}$ Regardless of statutory language, however, courts in forty-seven states have interpreted their realty tax laws to authorize assessors to consider all relevant facts, standards and assumptions. ${ }^{54}$ Consequently, the taxpayer's ability to predict his property's taxable value has been sacrificed in the interests of judicial and administrative flexibility.

\section{Assessment in the Courts}

Despite the obscurity of legislative policy and prevailing uncertainty over appraisal standards-both likely sources of extensive litigation-taxpayers rarely contest the assessor's techniques and assumptions. When a taxpayer's total assessment is low, a dispute is unlikely, for habitual administrative undervaluation then operates to convert large proportional errors into inconspicuous dollar amounts. Moreover, so long as market or business conditions remain relatively static, the annual re-use of previously established values limits the occasions for controversy. And if, notwithstanding these deterrents, complaints are raised, lawsuits frequently are avoided through negotiated compromises. ${ }^{55}$

52. E.g., Ariz. Code ANn. § 73-203 (1940); Ill. Ann. Stat. ch. 120, 501 (SmithHurd 1954); see appendix at p. 386 infra.

53. E.g., Ind. Stat. AnN. § 64-103 (1951); Neb. Rev. Star. ANn. § 77-201 (Supp. 1957); see appendix at p. 386 infra.

54. The general rule is that assessors and courts must consider "all factors" and may use any appropriate technique in ascertaining value. Some state statutes specifically require an "all factors" approach. See, e.g., Ind. Stat. ANN. § 64-103 (1951); Iowa CODE ANN. $§ 441.13$ (1949); Mirss. Code ANN. $\$ 9769$ (1953). Absent an "all factors" statute, courts read all statutory "value" terms as synonyms. Compare ME. Const. art. 9, § 8 ("just value") with Alfred J. Sweet, Inc. v. City of Auburn, 134 Me. 28, 180 Atl. 803,804 (1935) ("just value," "market value," and "true value" synonymous). Compare CAL. Rev. \& TAX. Code $\S \S 110,401$ (1956) ("full cash value" defined in terms of "payment of a just debt from a solvent debtor") with De Luz Homes, Inc. v. County of San Diego, 45 Cal. 2d 546, 290 P.2d 544, 554-55 (1955) (statutory formula means "market value" but all three standard valuation methods are appropriate). Compare WAsE. Rev. Coue ANn. $\$ 84.40 .030$ (1957) with Bellingham Community Hotel v. Whatcom County, 12 Wash. 2d 237, 121 P.2d 335, 338-39 (1942).

Wisconsin is the lone dissenter from the majority rule. Courts there read the statutory value language- "the full value which could ordinarily be obtained . . . at private sale" -to mean that the value obtained by the market-comparison test should always be determinative. Wis. StaT. $§ 70.32$ (1) (1955); 1 BoNBRIGHT 472-74 (collecting Wisconsin cases). Even in Wisconsin, capitalized income and depreciated reproduction cost may be considered as evidence of market value when sales data are lacking. See Buildings Development Co. v. Milwaukee, 225 Wis. 357, 274 N.W. 29 (1937); State ex rel. Flambeau Paper Co. v. Windus, 208 Wis. 583, 243 N.W. 216 (1932).

55. See Reuther, Management's View of State and Local Equalization in 49 NationaL TAX Ass'n, ProceEdings 455, 471-72 (1955). 
Judicial presumptions of administrative correctness further discourage taxpayers from having recourse to litigation. For instance, some courts deny review absent a showing of actual or constructive fraud. ${ }^{56}$ Others will examine contested assessments, but treat administrative valuations as conclusive unless the complainant overcomes them by the weight of substantial evidence..$^{57}$ In the jurisdictions which are most favorable to taxpayer litigation and litigating taxpayers, the presumption of administrative accuracy vanishes if the taxpayer produces some evidence of incorrect valuation or discrimination; a court then feels free to interpose its own judgment.58 Judicial presumptions to one side. the expense of assessment litigation can be especially prohibitive. When general undervaluation exists, the taxpayer may have to prove not only the proper tax value of his realty but also, through an independent appraisal of similar property, that his realty is assessed above the general level.59 The appraisal fees alone will usually be discouraging, especially since, if successful, the taxpayer would rarely save more than forty dollars for every thousand by which his assessment is reduced. ${ }^{60}$

55. The difficulty of proving constructive fraud seems to vary with the desire of the court to reach a particular result. Compare People ex rel. Rhodes v. Turk, 391 Ill. 424, 63 N.E.2d 513 (1945) (assessor's reliance on formula supports finding of fraud), with People ex rel. Toman v. Marine Trust Co., 375 Ill. 488, 31 N.E.2d 933, 935 (1940) (use of formula negates fraud). See Northwest Chemurgy Sec. Co. v. Chelan County, 38 Wash. 2d 87, 228 P.2d 129 (1951) (assessment at approximately 120\% of value sustained, but $400 \%$ assessment fraudulent).

57. See, e.g., Aetna Life Ins. Co. v. City of Newark, 10 N.J. 99, 89 A.2d 385 (1952); Bennett v. Board of Review, 234 Iowa 800,13 N.W.2d 351 (1944) (division of expert testimony; presumption not overcome) ; Mid-Continent Bldg. Co. v. Board of Equalization, 184 Okla. 525, 88 P.2d 626 (1939) (clear and convincing proof required).

58. See, e.g., Sibley v. Town of Middlefield, 143 Conn. 100, 120 A.2d 77 (1956) (court should ascertain value de novo); People ext rel. Beardsley v. Barber, 266 App. Div. 371, 43 N.Y.S.2d 588 (1943), aff'd, 293 N.Y. 706, 56 N.E.2d 587 (1944) (presumption vanishes when substantial counter-evidence is offered); Ahern v. Board of Equalization, 160 Neb. 709,71 N.W.2d 307 (1955) (presumption destroyed by assessor's failure to make personal inspection and by taxpayer's introduction of expert testimony).

59. The task of mustering sufficient appraisals may be formidable. See J. Rosenbaum \& Sons v. Coulson, 246 Iowa 848, 69 N.W.2d 403 (1955) (appraisal of 124 parcels insufficient to overcome assessor evidence based on 6 lots) ; Le Dioyt v. County of Keith, 161 Neb. 615, 637-38, 74 N.W.2d 455, 468 (1956) (24 appraisals inadequate). New York has attempted to ease the taxpayers' burden. See N.Y. TAX LAw $\$ \$ 292 \mathrm{a}$, 293 (effective Oct. 1, 1959, N.Y. Real Prop. TAX Law $\$ \S 716,720$ ). But with little success. See Holz, Reduction of Real Estate Taxes 4-5 (P.L.I. General Practice Series, rev. printing 1954) ; People ex rel. Ten Broeck Apartments Corp. v. Kinnaw, 276 App. Div. 722, 723, 97 N.Y.S.2d 511, 512-13 (1950) (dissenting opinion) (critically discussing New York standard for adequate proof).

60. Standard appraisal fees are $\$ 100$ per day. Small residential properties require at least a half day's work, and additional compensation must be paid for time spent testifying if settlement out of court is not achieved. Interview with Norman R. Benedict, M.A.I., Hamden, Conn., June 5, 1958; Letter from J. M. Cleminshaw Co., Cleveland, Ohio, to the Yale Law Journal, June 18, 1958, on file in Yale Law Library. Attempts to reduce costs by use of real estate dealers (and other less highly compensated experts) are likely to result in reduced judicial credence. See Le Dioyt v. County of Keith, supra note 59; J. Rosenbaum \& Sons v, Coulson, supra note 59. 
The relative infrequency with which the judiciary modifies assessor valuations has not produced administrative caprice. In fact, during the past thirty years many assessors have routinized their valuation procedures through various systems commonly referred to as "scientific assessment." Designed primarily to simplify the complexities of administering urban realty valuation, these systems universally employ depreciated reproduction cost to compute building values, and market-price comparisons to establish land values. ${ }^{61}$ Thus, "scientific assessment" comprises techniques which permit the application of construction cost tables, depreciation schedules and master land-value maps to the widest possible variety of sites and improvements. ${ }^{62}$ Uniform, if not equitable, distribution of the tax burden is facilitated, and the discretion of individual assessors is minimized. On the other hand, regularized procedures further insulate the assessors from litigation and, hence, from judicial supervision. Whenever litigation occurs, however, courts carefully preserve their power to review administrative standards, and to arrive at proper values by means other than "scientific assessment." 63

Judicial efforts to distribute the realty tax burden equitably are verbalized in terms of deciding which of the established appraisal techniques best effectuates the legislative mandate to assess according to a given standard, such as

61. For a general discussion of "scientific assessment" techniques, see TAYLOR, EconOmics of Public Finance 300-01 (rev. ed. 1953); 1 Bonbright 480-86.

62. "Scientific" land valuation is based on the appraisal of lots located at key positions in the community. These key lots are used to establish a standard value per front foot for lots of a certain depth. An agreed-upon formula is then used to adjust lots of other than standard depth, shape and location. "Scientific appraisal" also often involves public consultations designed to arrive at the standard value per unit. See 1 Bonbruger 480-84; Butler v. City of Des Moines, 219 Iowa 956, 957, 258 N.W. 755, 756 (1935).

Manuals are available listing average construction costs and standardized depreciation rates for various types of structures and supplying adjustment factors for regional variations in construction details. See, for example, Cleminshaw, Appraisers Manual (1947) (26 classifications priced); E. H. BoEckr \& Associates, Manual of Appraisals (3d ed. 1937). See generally Daniels v. Board of Review, 243 Iowa 405, 416-17, 52 N.W.2d 1, 7-S (1952).

For the use of land-value maps, see Butler v. City of Des Moines, supra at 957-59, 258 N.W. at 756; National Ass's of Assessing Officers, Urban Land Appraisat 55 (Assessment Practice Series No. 2, 1940).

63. See, e.g., Sibley v. Town of Middlefield, 143 Conn. 100, 120 A.2d 77 (1956) (judicial freedom); Iowa Bldg. Corp. v. Zirbel, 237 Iowa 242, 245, 21 N.W.2d 576, 579 (1946) (assessor must not rely solely on judgment of appraisal firm); Ahern v. Board of Equalization, 160 Neb. 709, 71 N.W.2d 307 (1955) (hired appraiser must not rely on only one method) ; North Side Laundry Co. v. Board of Property Assessment, Appeals \& Review, $168 \mathrm{~Pa}$. Super. 495; 497, 79 A.2d 215, 217 (1951) (court finds assessor's standard value also "actual value").

Occasional cases have reversed or affirmed "scientific" valuations because of the system used and without regard for the particular result. See People ex rel. Bray v. Golder, 83 N.Y.S.2d 186 (Sup. Ct. 1948) (scientific assessment considered no evidence of value); Citizens' Comm. for Fair Property Taxation v. Warner, 127 Colo. 121, 254 P.2d 1005 (1953) (across-the-board increase under "scientific" revaluation program approved). 
“market value." Since legislative standards are notoriously elastic and appraisal techniques rest partially on subjective assumptions, courts are able to settle assessment controversies on the basis of the particular economic needs of the community and the taxpayer. ${ }^{64}$ For instance, the user's ability to pay tends to control the resolution of conflicts over the assessment of "specialties"buildings constructed especially for one function and not readily adaptable to other uses. ${ }^{65}$ Courts nonetheless articulate decisions of this sort as attempts to reconcile or choose among the differing valuations which are produced by the capitalized-income, depreciated-reproduction-cost, and market-comparison approaches. ${ }^{66}$ Similarly, unprofitable land uses may secure subsidies in the form of reduced taxes; but the issue of subsidization is always framed as a question either of selecting among valuations representing reproduction costs, or of choosing lower figures derived from capitalized income or comparative sales. ${ }^{87}$ Likewise, disputes over the proper treatment of assessments during periods of generally rising or falling prices evoke judicial language about a "normal" period of realty values. ${ }^{68}$

Specialities. Courts have generally insisted that the owners of specialties pay taxes measured by earning capacity rather than the marketability of their property. Since a specialty is an improvement designed for a single, particular use, its potential sales price is frequently lower than its depreciated reproduction cost or its capitalized income. When seeking to maximize revenues, assessors are therefore likely to measure a specialty's value by the latter methods. Owners, of course, will then urge the appropriateness of market-comparison figures. If the specialty is a profitable one, the courts in most states will use its value to its owner as the proper standard and affirm administrative valuations based on the depreciated reproduction cost. ${ }^{69}$ A minority of states, on

64. Many decisions, however, represent little more than compromises between conflicting testimony. See, e.g., People ex rel. Hotel St. George Corp. v. Lilly, 268 App. Div. 830, 49 N.Y.S.2d 374, rev'd, 293 N.Y. 898, 60 N.E.2d 30 (1944). In other cases, the conflicting claims concerning appropriate figures are so far removed from reality that the courts accept any reasonable administrative action. See, e.g., Hammermill Paper Co. v. Erie, $372 \mathrm{~Pa}$. 85, $92 \mathrm{~A} .2 \mathrm{~d} 422$ (1952) (discussing relative merits of using 1941 and 1933 values in 1948 assessment).

65. For a definition of "specialty," see People ex rel. Sheffield Farms Co. v. Lilly, 270 App. Div. 812, 59 N.Y.S.2d 679, remanded, 295 N.Y. 354, 67 N.E.2d 579, restated òn remand, 270 App. Div. 1052, 63 N.Y.S.2d 92 (1946), aff'd mem., 296 N.Y. 798, 71 N.E.2d 771 (1947).

66. See cases cited notes $69-74$ infra.

67. See cases cited notes 80-87 infra.

68. See cases cited notes $92-95,98$ infra.

69. See People e.t rel. New York Stock Exchange Bldg. Co. v. Cantor, 221 App. Div. 193, 223 N.Y. Supp. 64 (1927); 1 BonBRIGHT 47479 (collecting cases). Property need not return much monetary income to be considered profitable; courts may characterize as profitable any property being used in accordance with the owner's intentions. Griffith v. Newark, 125 N.J.L. 57, 13 A.2d 860 (Sup. Ct. 1940) (store and office building designed partly as monument to owner); Eitingon v. Town of Stamford, 11 Conn. Supp. 241 (C.P. 1942), aff'd, 130 Conn. 418, 34 A.2d 878 (1943) (elaborate home rented to owner's relative at rate inadequate to support reproduction-cost assessment). 
the other hand, insist on market-comparison valuations, ${ }^{\mathbf{7 0}}$ but, by presuming the correctness of the assessors' figures, may allow the market value of specialties to be set at high levels which approximate reproduction costs. ${ }^{71}$ Under either the reproduction- or quasi-reproduction-cost approach, courts exact tax contributions from specialty owners which are in partial conformity with their ability to pay. Since the capitalized-income rationale-which would tax property strictly according to ability to pay-has been rejected in this context, a specialty owner's profits arising from his efficiency or entrepreneurial ingenuity cannot provide a basis for tax computations.

Extraordinarily profitable specialities are not valued strictly according to ability to pay, because capitalized-income and sales-price valuations can reflect the inadvertent inclusion of nonrealty items. Thus, assessors, unlike purchasers, of such structures as hotels and office buildings, may not incorporate furniture, equipment, or goodwill—or the capitalized earnings from personalty of this sort -in their valuations. ${ }^{2}$ In other cases capitalization is proscribed on the ground that business income may be partially attributable to a legal monopoly or some other unique commercial advantage. ${ }^{73}$ Simplifying the difficult task of segregating the realty and personalty elements in earnings capitalizations or sales figures, courts have adopted depreciated reproduction cost as a ceiling on specialty assessments. ${ }^{74}$ The judiciary has thereby accomplished, albeit crudely, necessary distinctions between realty and personalty, for personalty is, by statute or administrative practice, either fully tax-exempt or subject to lighter taxes than realty. ${ }^{\mathbf{7 5}}$

70. See State ex rel. New Lisbon State Bank v. City of New Lisbon, 260 Wis. 607, 51 N.W.2d 509 (1952) (depreciated-reproduction-cost valuation of bank disapproved); State $e x$ rel. Northwestern Mut. Life Ins. Co. v. Weiher, 177 Wis. 445, 188 N.W. 598 (1922) (depreciated-reproduction-cost valuation of insurance home office reduced).

71. State $e x$ rel. North Shore Development Co. v. Axtell, 216 Wis. 153, 256 N.W. 622,624 (1934).

72. People ex rel. Hotel Paramount Corp. v. Chambers, 298 N.Y. 372, 83 N.E.2d $\$ 39$ (1949) (hotel) (collecting cases); Gibbs v. State Bd. of Taxes \& Assessment, 101 N.J.L. 371, 129 Atl. 189 (Ct. Err. \& App. 1925) (forbidding valuation based on rent). Compare Simms v. Los Angeles County, 35 Cal. 2d 303, 217 P.2d 936, 944 (1950).

73. People e.x rel. Delaware, L. \& W.R.R. v. Clapp, 152 N.Y. 490, 46 N.E. 842 (1897). The monopoly value may flow from unique commercial position. See People ex rel. Empire State Bldg. Corp. v. Boyland, 1 Miisc. 2d 518, 523-24, 135 N.Y.S.2d 764, 769 (Sup. Ct. 1954), aff'd mem. sub nom. In the matter of Empire State Bldg. Corp. v. Boyland, 1 App. Div. 2d 770, 149 N.Y.S.2d 214 (1956) (no addition to land value because it is site of unique building). But if the monopoly results from a physical feature of the land, the added value is attributable to realty. Cf. Natatorium Co. v. Bd. Com'rs, 67 Idaho 143, 150-51, 174 P.2d 936, 939-40 (1946) (concurring opinion) (income due to natural spring properly attributable to realty).

74. People $c x$ rel. Parklin Operating Corp. v. Miller, 287 N.Y. 126, 38 N.E.2d 465 (1941) (loft and office building); People ex rel. Manhattan Square Beresford, Inc. v. Sexton, 284 N.Y. 145, 29 N.E.2d 654 (1940) (apartment house) (collecting cases). No cases involving specialties have been found allowing assessment at more than reproduction cost.

75. See note 1 supra. 
Subsidies. If an owner's profit expectations are not realized, courts will often grant him a measure of tax relief. Although admittedly a stumbling-block to the optimum allocation of productive resources, this assistance for marginal or ailing businesses is a manifestation of the same policy which underlies legislation like the protective tariff, ${ }^{76}$ the Reconstruction Finance Corporation Act, ${ }^{77}$ the reorganization chapter of the Bankruptcy Act, ${ }^{78}$ and the loss carryover provisions of the Internal Revenue Code. ${ }^{79}$ Under the realty tax, this policy is phrased in terms of "value." If a court finds that a parcel's value has been impaired through obsolescence, it will usually grant relief by authorizing appropriate deductions from depreciated reproduction cost, or by decreeing that the capitalization of income is the proper assessment procedure. If, however, the court attributes the parcel's subnormal income to the occupant's mismanagement, concessions of this sort are refused on the ground that only the property's income, not its inherent value, is affected.

If an obsolete structure has actually been sold, or is of a type which is actively traded, a court seeking to reduce the property's assessment can do so by relying on the relevant market price. ${ }^{80}$ Thus, a court assessed at $\$ 100,000$ a mansion which had been built at a cost of $\$ 1,000,000$ and which, judging from its recent history of sales induced by unprofitable uses, could neither be sold nor attract developmental capital if assessed at its reproduction cost. ${ }^{81}$ On the other hand, when property with impaired earnings has no ascertainable market price, its obsolescence can be recognized through standard income-capitalization techniques. ${ }^{82}$ And if suitable sales and income data are unavailable, tax liability may be reduced by postulating the price at which the structure could be marketed. ${ }^{83}$ Whatever the method by which valuations below depreciated reproduction

76. See, e.g., Tariff Act of 1930, 46 Stat. 687, 19 U.S.C. § 1303 (1952).

77. 61 Stat. 202 (1947).

78. Bankruptcy Act ch. X, 52 Stat. 883 (1938), 11 U.S.C. $\S 5501-676$ (1952).

79. INT. REv. CODE of 1954, $\$ 172($ b).

80. See, e.g., People ex rel. McGaughey v. Wilson, 367 Ill. 494, 12 N.E.2d 5 (1937) (seventy-five-year-old three-story business building); People $e x$ rel. The Lincoln, Inc. v. Boyland, 279 App. Div. 882, 110 N.Y.S.2d 797 (1952) (facts set forth in dissenting opinion), rev'd, 306 N.Y. 817, 118 N.E.2d 824 (1954) (hotel); People ex rel. Beardsley v. Barber, 266 App. Div. 371, 43 N.Y.S.2d 588 (1944) (lake-front resort property); Skyline Swannanoa, Inc. v. Nelson County, 186 Va. 878, 44 S.E.2d 437 (1947) (estate bought for use as motel). But actual sales price is not controlling where time and a new owner restore the property to serviceability. 22 Charlotte, Inc. v. Detroit, 294 Mich. 275, 293 N.W. 647 (1940) (hotel).

81. Skyline Swannanoa, Inc. v. Nelson County, supra note 80.

82. Assessors of Quincy v. Boston Consol. Gas Co., 309 Mass. 60, 34 N.E.2d 623 (1941) (gas mains); Colonial Life Ins. Co. v. Jersey City, 18 N.J. Misc. 60, 11 A.2d 14 (B.T.A. 1940) (garage) ; People ex rel. The Lincoln, Inc. v. Boyland, 279 App. Div. 882, 883, 110 N.Y.S.2d 797, 799 (1952) (dissenting opinion), rev'd, 306 N.Y. 817, 118 N.E.2d 824 (1954) (hotel).

83. Thus, where a factory building was so obsolete that a valuation expert "could not conceive of any intelligent industry" buying "such an outmoded set of buildings," a depreciated-reproduction-cost assessment was lowered, although the instant occupant had 
cost are computed, they subsidize modernization and encourage the continued operation of industries basic to the economy of their communities.

No owner, however, can escape taxation altogether simply because his real estate is obsolete. Failure to liquidate an unproductive building indicates that its owner prizes its liquidation price less highly than the chance of improved earnings. Hence, assessments are not reduced below salvage value, even when obsolescence is recognized. ${ }^{84}$ Besides assuring that all owners will assume some tax burden, the salvage-value floor is consistent with the dictate of sound land policy that permanently unprofitable uses be terminated.

Unlike value lost through obsolescence, low returns caused by mismanagement are seldom grounds for tax relief. Reasoning that a parcel's value is a function of its earning capacity, not its actual yield, courts ignore the consequences of managerial ineptitude. ${ }^{85}$ Accordingly, the market prices of comparable buildings in other than distress sales are used to assess conventional structures, since these prices are based on the expectations of purchasers rather than the experience of sellers. ${ }^{86}$ In assessing specialties, however, sales data on comparable structures are usually unavailable, and income capitalization must therefore be utilized. The effects of mismanagement are here excluded by deriving assessments from the earnings of a typical, well-managed specialty of the same

proved no loss of income. City of Trenton v. John A. Roebling Sons, 24 N.J. Super. 213, 219, 93 A.2d 785, 788 (App. Div. 1953). See National Folding Box Co. v. Board of Tax Review, No. 51499, Ct. C.P., New Haven County, Conn., Apr. 2, 1957. But see Crucible Steel Co. v. Board of Property Assessment, Appeals \& Review, 356 Pa. 373, 52 A.2d 190 (1947) (rejecting obsolescence argument when advanced in support of salvage-value assessment of going steel plant).

84. [I]f the enterprise reaches the irreducible minimum as an enterprise and is abandoned, its property is sold for its fair value on the open market. The assessors are required by law to ascertain that value and make their assessments accordingly. Even if a railroad is defunct as an entity, the value of its real estate apart from utilization for railroad purposes is not only assessable, but it must be assessed "at the full value thereof."

People $c x$ rel. Lyford v. Allen, 286 App. Div. 621, 626, 146 N.Y.S.2d 186, 190-91 (1955); cf. People e.r rol. Toman v. Marine Trust Co, 375 Ill. 488, 31 N.E.2d 933 (1941).

85. "[E]arning capacity and actual earnings are by no means identical. What the property efficiently managed should have earned, and not what it has earned under incompetent operation, is the earning capacity that throws light on value." Harris Trust \& Sav. Bank v. Earl, 26 F.2d 617, 618 (8th Cir. 1928) ; see Pitney v. Kelly, 21 N.J. Misc. 405, 34 A.2d 547 (B.T.A. 1943) (railroad poorly, if not improperly, run); cf. McArdle's Estate v. City of Jackson, 215 Miss. 571, 61 So. $2 d 400$ (1952) (partially vacant land valued as if adequately improved).

86. Cf. 22 Charlotte, Inc. v. Detroit, 294 Mich. 275, 293 N.W. 647 (1940) (purchaser of defunct hotel restored productivity by repairs; purchase price not controlling). Statutory language, see appendix at p. 386 infra, is so clear that taxpayers have rarely urged that purchase prices in distress sales are evidence of value. An analogous question arises when an owner allows property to be foreclosed for taxes, and purchasers at a tax sale seek to reduce assessment to the tax-sale price. Such reductions have been consistently denied. See, e.g., Davis v. Division of Tax Appeals, 135 N.J.L. 250, 51 A.2d 437 (Sup. Ct. 1947); Tidball v. Miller, 72 S.D. 243, 32 N.W.2d 683 (1948). 
sort rather than from the assessed specialty's actual receipts and expenditures. ${ }^{87}$ Although this procedure does not comport with the judicial policy of favoring low-profit enterprises, it obviates the collection and analysis of the income records of every individual speciality. ${ }^{88}$

Business Cycles. In order to maintain the solvency of municipalities, assessment reductions have frequently been denied in the face of general, coincident declines in the profits, construction costs and sales values of real property..$^{s 0}$ During the Great Depression, realty owners who suffered economic hardship were logical candidates for tax relief. But restrictive statutes, which limited local taxing and borrowing power to specified proportions of total assessed valuations, forced municipalities either to maintain the level of realty assessments or to neglect mounting welfare obligations. ${ }^{90}$ Furthermore, payroll cuts and other depression-created cost economies were offset by widespread tax delinquencies. ${ }^{91}$ Assigning municipal solvency paramount importance, ${ }^{92}$ courts averted fiscal shipwreck by developing the concept of the "normal" market. Under this doctrine, low computations of value resulting from depressed business conditions were in effect rejected, and the courts' estimates of value under normal conditions were employed instead. ${ }^{93}$ In some states, the courts relied on statutory language barring assessments based on prices obtained at fore-

87. See Aetna Life Ins. Co. v. City of Newark, 10 N.J. 99, 89 A.2d 385, 389 (1952) (department store earnings not relevant to valuation of department store building) (collecting cases); Prudential Ins. Co. of America v. Division of Tax Appeals, 133 N.J.L. 153, 43 A.2d 271 (Sup. Ct. 1945) (apartment house) ; In re Melcroft Corp., 256 App. Div. 291, 10 N.Y.S.2d 27 (1939) (only reasonable costs allowed in determining net income).

88. See Luce, Assessment of Real Property for Taxation, 35 MrCH. L. Rev. 1217, 1230-31 (1937).

89. See generally 1 BonBRIGHT 163-72; Luce, supra note 88 .

90. From 1927 to 1932, the property tax revenues of local governments dropped from $\$ 4,360,000,000$ to $\$ 4,159,000,000$. Public welfare expenditures, on the other hand, rose from $\$ 111,000,000$ in 1927 to $\$ 370,000,000$ in 1932 and $\$ 526,000,000$ in 1934. The state and federal governments recognized the financial squeeze on localities and increased their aid programs. U.S. Census, Historical Statistics on State and Local GovernMiENT FiNances 1902-1953, at 21 (State and Local Government Special Study No. 38, 1955).

91. See Note, 46 Harv. L. Rev. 1317, 1320-21 (1933); Note, Propriely of Raising Municipal Tax Rate to Allow for Delinquencies, 43 Y ALE L.J. 143 (1933).

92. "Violent fluctuations in municipal income are not desirable, and assessors in listing values may, to a certain extent, disregard the excesses of a boom as well as the despair of a depression." Alfred J. Sweet, Inc. v. City of Auburn, 134 Me. 28, 180 At1. 803, 804 (1935). See also Amory v. Assessors of Boston, 306 Mass. 354, 28 N.E.2d 436 (1940); Amory v. Assessors of Boston, 310 Mass. 199, 37 N.E.2d 459 (1941).

93. See, e.g., Somers v. City of Meriden, 119 Conn. 5, 174 Atl. 184 (1934); City Holding Co. v. State Bd. of Tax Appeals, 127 N.J.L. 168, 21 A.2d 289 (Sup. Ct. 1941); Appeal of Kliks, 158 Ore. 669, 76 P.2d 974 (1938). Another route to the same result was the argument that to reduce the assessment of the litigating taxpayer to reflect depression values would create inequality vis-à-vis nonlitigating taxpayers. See Sloman-Polk Co. v. Detroit, 261 Mich. 689, 247 N.W. 95 (1933), 33 ColuM. L. Rev. 758. But see Detroit v. Detroit \& Canada Tunnel Co., 92 F.2d 833 (6th Cir. 1937) (effect of depression on earn- 
closure sales. ${ }^{04}$ In others where express legislative guidance was lacking, judicial decisions were bottomed on the "inherent" meaning of "value."95

Even after the economic tide had turned and inflationary pressures increased the revenue demands of municipalities, "normal market" concepts remained in vogue. Nor have they been abandoned despite continued pressures for the release of additional taxing, borrowing, and spending power. ${ }^{96}$ The judiciary has evidently recognized the inequity of abandoning the normal-market standard before taxpayers could recoup their overpayments in depression years. In any event, courts have not overruled the assessors' adherence to that standard. Thus, taxpayers have benefited from the implicit extension of judicial language about inherent value to cover an area-valuations in inflationary periodsalmost completely free of legislative guideposts. ${ }^{97}$ Today, assessments are made and reviewed in terms of a normal period, usually one somewhere around 1940.98 As a result, communities have doubtless been forced to curtail their taxation, spending, and level of services.

ings must be considered) ; Portland Silk Co. v. City of Middletown, 125 Conn. 172, 4 A.2d 422 (1939) (adopting depression market figure). In both the tunnel and silk company cases, reduced assessments reflected obsolescence as well as general market declines.

94. See, e.g., Appeal of Kliks, supra note 93, at 672-73, 76 P.2d at 976 (statute called for "amount such property would sell for at a voluntary sale made in the ordinary course of business"). Compare City Holding Co. v. State Bd. of Tax Appeals, supra note 93, zuith N.J. Stat. AnN. \$ 54:4-23 (Supp. 1957).

95. See, e.g., Somers v. City of Meriden, 119 Conn. 5, 174 Atl. 184 (1934); Alfred J. Sweet, Inc. v. City of Auburn, 134 Me. 28, 180 Atl. 803 (1935).

96. Local expenditures for education increased steadily from $\$ 2,304,000,000$ in 1944 to $\$ 6, \$ 24,000,000$ in 1952 . Highway expenditures showed a similar increase from $\$ 660,000$,000 to $\$ 2,094,000,000$ and, under pressure of increased living costs, welfare outlays had increased to $\$ 1,378,000,000$ in 1952 from a 1944 level of $\$ 556,000,000$. Most spectacular in relative increase were local investments in housing and community redevelopment, which multiplied nearly twenty-fold from $\$ 46,000,000$ in 1944 to $\$ 766,000,000$ in 1952. U.S. Census, op. cit. supra note 90 , at 21 .

97. Maryland alone has legislation expressly covering assessments in periods of inflation. MD. Code ANn. art. 81, § 14 (Supp. 1957).

98. Since assessors have generally adopted a policy of self-restraint and have predicated values on a period of normalcy, few occasions have arisen for direct judicial action. Sce Martin, Relationship Between the Property Taxes and the Economy, in 45 National Tax Association, Proceedings 47, $52-55$ (1952); Newcomer, The Decline of the General Property Tax, 6 NaT'L TAX J. 38, 47 (1953). Courts have, however, approved administrative practices by inference. See, e.g., State Tax Comm'n v. Brandt Cabinet Works, 202 Md. 533, 539, 97 A.2d 290, 291-92 (1953) (assessors used table of 1940-1941 costs for old buildings and adjusted new building costs to 1940-1941 basis "on the theory that [this] . . . reached actual cash value undistorted by temporary inflation"); Hammermill Paper Co. v. Erie, 372 Pa. 85, 92 A.2d 422 (1952); Daniels v. Board of Review, 243 Iowa 405, 52 N.W.2d 1, 8 (1952) (1943 values used by assessor because "realistic"). In cases in which administrators have rejected "normal value," judges have voiced reproving dicta. See City of Newark v. West Milford Tp., 9 N.J. 295, 88 A.2d 211, 216 (1952) (general rise in realty prices not support for increased assessment of watershed land; remanded on other grounds). Unreported cases may have held that "normal value" is the invariable standard. See Haig \& Shoup, The Financial Problem of THE City uf New YoRk 139 \& n.16 (1952). 


\section{Legislative Policy}

A useful if elusive concept for the judiciary, "value" provides a less-thansatisfactory framework for legislative policy making. Accordingly, few states have bothered to refine this concept. ${ }^{99}$ Rather, statutes in all states authorize particular interest groups to take deductions from their property valuations, or to pay other, lighter taxes in lieu of realty levies. ${ }^{100}$ Veterans, for instance, have long been rewarded by special, fixed-amount deductions from the assessed value of their real property. ${ }^{101}$ Owner-occupants of homes and farms receive similar treatment $;^{102}$ and farmers have exerted sufficient pressure to secure additional

99. For attempts at defining value to meet the demands of particular situations, see N.M. CoNST. art. 8, $\$ 6$ ("plowing of land shall not be considered as adding value thereto for the purpose of taxation"); Wrs. STAT. $\$ 70.325$ (1955) ("time and expense necessary to market the lots" to be considered by assessor in valuing subdivision).

100. See generally Newcomer, The Growth of Property Tax Exemptions, 6 NAT'L Tax J. 116 (1953).

101. See generally Spears, Veterans' Property Tax Exemptions, 11 NaT'L Tax J. 129 (1958). Twenty-eight states have veterans' exemptions. Exemptions are limited to disabled veterans in 14 of the 28 states; 7 grant larger benefits to disabled than to other veterans; and the remaining 7 accord identical treatment to all veterans. Widows and orphans of veterans commonly get similar exemptions. Ibid.

The size of a typical exemption varies from $\$ 500$ in New Jersey to $\$ 5,000$ in New York and Louisiana; but the real significance of any dollar amount cannot, of course, be comprehended unless the ratio of assessed to computed value is also known. Id. at 132-33.

California's exemption is conditioned on ownership of property assessed at less than $\$ 5,000$; and the Idaho disability exemption applies only to those with less than $\$ 3,600$ in property or annual income. CAL. CoNst. art. 13, § 11/4; IDAHo CoDE ANN. $\$ 63-105$ (4) (e) (Supp. 1957).

102. This homestead exemption is patterned after that applicable when a debtor's property is subject to judicial sale. The purpose of the exemption is "(1) to recognize and give effect to the principle of tax free homes as a public policy ..., (2) to encourage homebuilding and ownership, and (3) to give additional security to family groups." Miss. Code ANn. $\$ 9714$ (1952). "Homestead" generally includes owner-occupied residences and owner-operated farms; but in many cases it also extends to any real property, regardless of use, with varying limitations as to value and size. See generally Comment, State Homestead Exemption Lazes, 46 YALE L.J. 1023, 1036-40 (1937) ; Note, Homestead Tax Relief, 23 Iowa L. Rev. 67 (1937) ; Crosby \& Miller, Our Legal Chameleon, The Florida Homestead Exemption: $V, 2$ U. FLA. L. Rev. 346, 372-75 (1949).

Eleven states exempe homesteads from realty taxation. Ala. Cone ANN. tit. 51, $\$ 15$ (1941) ( $\$ 2,000$ or 160 acres); Fla. Stat. AnN. $\$ \$ 192.12, .14, .19$ (1943) $(\$ 5,000)$; GA. Const. art. 7, $\$ 2-5404$ ( $\$ 2,000$ exemption from state taxes only); Iowa Cone Aiss. $\$ \$ 425.1, .11$ (Supp. 1957) (partial exemption of $\$ 2,500$ or, in urban areas, one-half acre); LA. Const. art. $10, \S \S 4(9), 4(9)$ (a) (\$2,000 or 160 acres) ; Minn. Stat. Ann. $\$ 273.13$ (1947) ( $\$ 4,000$ exempt from state tax; urban homesteads assessed at $25 \%$ instead of normal $40 \%$ of computed value; rural homesteads at $20 \%$ instead of normal $33 \% 3 \%$ ); Miss. Code Ann. $\$ 9714$ (1942) ( $\$ 5,000)$; N.C. Const. art. $5, \S 5(\$ 1,000)$; OxLA. Const. art. 12-A, \$ 1; ORLA. Stat. ANn. tit. 68, \$\$ 33, 34 (1954) ( $\$ 1,000$ or 160 acres if rural, or 1 acre if urban); S.D. CoDE $\$ 57.0311(7)$ (1939) (homestead exempt from state tases); Tex. Const. art. 8, \$ 1-a; Tex. Rev. Civ. Stat. ANN. art. 7048a, \$ 2 (1951) $(\$ 3,000$ exempt from 30-mill county road tax) ; UTA CoNST. art. $13, \$ 2$ (\$2,000 exemption authorized; never enacted); Wyo. Comp. Stat. Ann. $\$ 32-105$ (1945) $(\$ 5,000)$. Several other 
exemptions for certain agricultural improvements. ${ }^{103}$ Likewise, urban influence has produced measures favoring the construction and rehabilitation of apartment buildings. ${ }^{104}$ Competition among the states for new industry has resulted in permissive or mandatory exemptions for sought-after enterprises. ${ }^{105}$ Analogous concessions have been accorded endeavors like timber operations and the development of residential subdivisions. ${ }^{106}$ And transportation, mining and other industries have been permitted to pay lower franchise and income taxes instead of their realty taxes. ${ }^{107}$ Exemptions and substitute taxes thus permit legislatures to effect social and economic policy without formally abandoning "value" as an assessment standard.

states have similar exemptions from personal property taxes. See, e.g., CAL. CoNST. art. $13, \S 10 \% / 2$; CAL REV. \& TAX. CODE $\S \S 210,210.5$ (1956).

103. See, e.g., Cal. Const. art. 13, § 123/4; Cal. Rev. \& TaX Code $\S 211$ (1956) (growing crops, trees and vines exempt) ; CoLo. Const. art. 10, $\$ 3$; Colo. Rev. STat. ANN. $\$ 137-12-3(4)$ (Supp. 1957) (irrigation ditches exempt); N.C. Gen. Stat. ANN. § 105-294 (Supp. 1957) (terracing and other soil conservation improvements exempt). See also Minns. Stat. Ann. $\$ 273.13$ (Supp. 1957) (ratio of assessed to computed value: rural homestead $20 \%$, other rural $331 \% \%$, urban homestead $25 \%$, other urban $40 \%$ ) ; Henry, The Farmers' Tax Burdent, 4 NAT'L TAX J. 341 (1951).

104. New York State has enacted four such measures. The first, passed in 1920, allowed localities to exempt until 1932 all new buildings used for dwellings. N.Y. Laws 1920, ch. 949 at 2487 (as amended, N.Y. TAX LAw $\S 5$ ). In 1936, New York City was authorized to exempt for five years value added by alterations if the value of the remodeling was less than the value of the building. N.Y. Laws 1936, ch. 474, at 1190 (as amended, N.Y. TAX LAw § 5-a). In 1939, all cities except New York City were given power to arrange a twenty-year assessment freeze in exchange for the owner's expenditure on rehabilitation of an amount equal to twice the assessment. N.Y. Laws 1939, ch. 754, at 1796 (now N.Y. TAX LAw $\$ 5-b)$. In 1946, all localities were authorized to allow exemptions sufficient to enable an owner to recover, over a period of eight or twelve years, the cost of installing central heating and adequate plumbing. N.Y. Laws 1946, ch. 321, at 882 (now N.Y. TAX LAw $\S 5-c$ ). Compare LA. CoNst. art. 10, 19 (owner-occupied dwellings built after adoption of amendment partially exempt for limited time).

105. See, e.g., Ala. Code AnN. tit. 51, § 3 (Supp. 1955) (new factories may be exempted by contract for 10 years) ; GA. CODE ANN. \$\$ 92-206 (1937) (new industry may be exempted from local taxes by referendum); LA. CoNsT. art. 10, $\$ 4(6)$ (industries located on New Orleans Canal exempted if investment exceeds $\$ 25,000$ and at least 25 persons are employed); cf. VT. STAT. $\$ 655$ (1947) (personal property of industry occupying previously vacant building and involving $\$ 10,000$ investment may be exempted by town vote).

State development authorities evidently place great reliance on such devices, for tax benefits are universally featured in promotional publications. See, e.g., N.Y. Times, Apr. 6, 1958, \$ 3, p. 9, col. 5 ("South Carolina passes law reducing taxes on industry") ; id., May $4,1958, \S 10$, p. 22, col. 3 ('Tax comparisons favor New York; no 'hidden costs' in state's levy").

106. See, e.g., Conn. Gen. Stat. $\$ 1781$ (1941) (timber land); Iowa Code Ann. § 441.14 (1949) (forest and fruit trees); MD. ANN. ConE art. 81 , 19 (1957) (subdivided farm land); Wrs. STAT. $\$ 70.325$ (1955) (subdivisions).

107. See, e.g., CoLo. Rev. Stat. ANn. $\$ 137-5-4(2)$ (1953) (mines specially assessed according to gross income); Conn. Public Acts 1957, No. 515, § 4, at 738 (gross receipts tax on motor bus companies); Ore. Rev. STAT. $\$ \S 308.705-.730$ (1957) (optional gross receipts tax for rural telephone exchanges); cf. Ind. Stat. ANn. \$ 64-744 (1951) (vessels taxed according to tonnage). 


\section{Administrative Practices}

To achieve their policy goals, assessors utilize both the value-manipulation techniques of the judiciary and the exemption approach of the legislatures. Occasionally, judicial review compels assesors to justify their results in terms of value. Generally, however, the infrequency of review permits a relatively free exercise of the administrative power to grant partial exemptions through underassessment; and, except in the context of litigation, assessors appear as proponents of various taxpayer groups rather than as champions of the exchequer. Thus, during the boom of the 1940's and 1950's, the normal-market doctrine, which had been employed in depression years to maintain assessments and to prevent fiscal collapse, ${ }^{108}$ was retained despite municipal entreaties that it be abandoned. ${ }^{109}$ Other assessor policies favor particular classes of taxpayers. Industries regarded as essential to the local economy are often attracted or retained by informal agreements to underassess. ${ }^{110}$ Homeowners in many areas benefit from a lower ratio of assessed to computed value than that applied to commercial property. ${ }^{111}$ In addition, assessors commonly assign lesser values to land on which houses are built than to identical lots in the same neighborhood which are used commercially. ${ }^{112}$

Haphazard administrative policy frequently produces residential valuations which bear an inverse relationship to the owners' ability to pay. As property values increase, assessments tend to be at lower percentages of computed values. ${ }^{113}$ The proclivity of more prosperous realty owners to seek reductions may afford a partial explanation; and assessors may unconsciously harmonize their computations with the interests of those who are politically dominant and well-to-do. Also highly significant is the relative unfamiliarity of poorly paid, inexpert assessors with the "values" of expensive homes. 114 Uniformity is more likely to be achieved by professional assessors employing scientific procedures, but neither administrative skill nor judicial regulation currently offer effective guarantees against political influence.

108. See Shannon, The Conflict Between Law and Administrative Practice in Valuation of Property For Taxatron in Kentucky 20-22 (1957) (maintenance of assessments in face of falling values produced full value assessments); Zangerle, Tax Assessments During a Depression, 15 Public Manageanent 300, 305 (1933).

109. See note 98 stipra.

110. McLaughtin \& Robock, Why Industry Moves Sauth 114 (Nat'l Planning Ass'n, Comm. of the South, Rep. No. 3, 1949) ; Snell, Tax Exemptions to Encourage Industry, 29 TAXES 383, 385-86 (1951).

111. New Jersey Comm'n on State Tax Poltcy, The General Property Tax in New Jersey 102 (6th Rep. 1953); Haig \& Shoup, The Financial Problem of the City OF NEW YORK 136-39 (1952).

112. See J. Rosenbaum \& Sons v. Coulson, 246 Iowa 848,69 N.W.2d 403 (1955).

113. New Jersey Comm'N on State Tax Policy, op. cit. supra note 111, at 94-101; Silverherz, The Assessment of Real Property in the United States 53 (10th Rep. N.Y. State Tax Comm'n, 1936).

114. See Allen \& Brownlee, Economics of Public Finance $411-12$ (1947). 


\section{Summary}

The elusiveness of "value" has been maintained and exploited by legislative, judicial, and administrative processes. Although a less malleable standard might dispel taxpayer confusion, courts applying such a standard would find it difficult to achieve suitable assessment adjustments for specialties, unprofitable uses, and financially needy spending authorities. ${ }^{115}$ Similarly, to specify valuation techniques with precision would simplify the assessor's task but diminish his power to adjust conflicting interests. Therefore, uncertain assessment standards must persist so long as legislative policy is geared solely to creating exemptions for insistent pressure groups.

\section{Recent Attempts at Reform}

Without amplifying the fundamental statutory approach to realty taxation, many legislatures have recently taken steps in the direction of inhibiting the administrative manipulation of assessments. New measures have been added to supplement the recognized inadequacies of politically inspired tax exemptions, unfettered judicial discretion, and conventional uniformity clauses and equalization boards. ${ }^{116}$ Some states have initiated general studies of valuation methods and problems of tax administration. ${ }^{117}$ Others have authorized local programs designed to accomplish the independent reappraisal of all realty. ${ }^{118}$ A few states, either in conjunction with a program of reappraisal or separately, have empowered a central administrator to promulgate rules and regulations defining more clearly the existing constitutional and statutory standards of "value."110

115. "On the whole, the courts have done well to avoid the formulation of any rigid standard for the guidance of assessing officials. The legislatures or the people, as the case may be, would likewise do well to repeal the market value rule and leave the courts and the assessing officials free to work out the process of tax valuation as changing economic conditions require." Luce, Assessment of Real Property for Tazation, 35 Mrce. L. Rev. $1217,1241-42$ (1937).

116. For a summary of recent legislation and administrative activity, see Gronouski, State Supervision of Property Tax Administration, 10 NAT'L TAX J. 158 (1957).

117. See, c.g., Nev. Rev. Stat. $\$ 360.180$ (1957).

118. See, c.g., ArIz. Code Ann. \$§ 73-121 to -123 (Supp. 1952).

119. The following provisions of the Arkansas act typify this innovation.

Section 3. . . . the [Public Service] Commission shall do the following:

Prepare and promulgate Real Estate Assessment Manuals for the use and guidance of County Assessors and County Equalization Boards. . . .

Section 4. The appraisal and assessment shall be according to value as required by ... the Constitution. . . .

Section 5. It shall be the duty of the County Assessors and their deputies to use and follow the assessment manuals and standards promulgated by the Commission .... .

Ark. Acts 1955, act 153, at 359.

For similar legislation, see Md. Laws 1954, ch. 72, at 248 (now MD. CoDE ANv. art. 81, § 232(2) (Supp. 1957)) ; Ohio Laws 1957, ch. 109, at 65 (now OHio Rev. Code ANN. 
The acts providing for further studies have not yet borne fruit. Ultimately, they will be only as effective as their legislative end-products. Laws fostering the use of independent, professional appraisers, rather than political appointees, have improved the skill and consistency with which available assessment techniques are used, but leave undiminished the fundamental discretion reserved to assessors and assessment reviewers. ${ }^{120}$ The most ambitious of the reforms undertaken - the statutes vesting clarification powers in a state tax administrator-have to date resulted in rules and regulations which fail to correct many sources of regressivity, political distortion, and taxpayer uncertainty. The central administrators have in fact achieved little more than would also be possible under the more modest legislation sanctioning independent reappraisals.

All promulgations under the rules-and-regulations statutes have followed the methods of "scientific assessment." Accordingly, improvements are valued on the basis of depreciated reproducton cost, and land by the market-comparison method. ${ }^{121}$ This separate valuation of land and improvements is sensible, administratively and socially, for it permits opposing policy considerations to receive expression in the assessment of a given.parcel. Moreover, the consistent treatment of all parcels is facilitated if land-use policies are manifested in terms

$\S \$ 5703.02(\mathrm{k}$ ), 5713.03 (Page Supp. 1958)) ; Wyo. Laws 1957, ch. 171, § 1, at 283 (now Wyo. Comp. Stat. Ann. \$ 32-506 (Supp. 1957)).

Comparable laws in Florida, Nebraska and Washington have not been put into effect by administrators. Fla. Laws 1943, ch. 22079, § 46, at 888 (now FLA. STAT. AnN. $§ 192.31$ (Supp. 1957)) ; Letter from General Counsel, Office of the Comptroller, State of Florida, to the Yale Law Journal, April 25, 1958, on file in Yale Law Library; Neb. Laws 1957, ch. 322, § 1 (now Neb. Rev. Stat. Ann. § 77-303 (Supp. 1957)); Nebraska State Tax Comin's, Assessors' Handbook and Rules and Regulations For the Assessment of Property 1958, rule 3; [1958] County Assessors' Assoctatton of Nebraska, Proceedings 35; Wash. Laws 1955, ch. 251, § 9, at 1030 (now Wash. Rev. Code ANn. § 84.41.090 (Supp. 1957)) ; Letter from Supervisor, Assessment Standards Division, Washington State Tax Comm'n, to the Yale Law Journal, June 3, 1958, on file in Yale Law Library. A rules-and-regulations statute has been enacted in Oregon to become effective in 1961. Ore. Laws 1953, ch. 701, $\$ 2$, at 1363 (now ORE. Rev. Stat. $\$ 308.205$ (2) (Supp. 1957)).

120. For an act contemplating independent appraisals by private firms, see WAsB. Rev. CoDE ANN. $\$ \S 84.41 .010-.120$ (1957). For an act requiring that public assessors be professionally qualified appraisers, see ORE Rev. Stat. $\$ \S 308.010, .231$ (1957).

121. See Arkansas Assessment Coordinating Division, Assessors Manual passim (1956) [hereinafter cited as ARK. MANuAL]. The Arkansas state tax authorities compiled and published this 199-page assessor's manual, which contains detailed instructions for mapping, classifying and valuing land, and provides cost and depreciation tables for assessing improvements. The Maryland and Wyoming authorities adopted a commercial appraisers' handbook, the Boeckh Manual of Appraisal, as standard. Maryland State Tax Comm'n, Letter of Instructions to Assessing Officials § 3(d) (March 12, 1958) [hereinafter cited as Md. Instructions] ; Letter from Director, Ad Valorem Tax Department, Wyoming Board of Equalization, to the Yale Law Journal, June 5, 1958, on file in Yale Law Library. The Ohio regulations outline a "scientific assessment" method based on landvalue maps and building cost schedules prepared by county officials. OHIO BOARD OF TAX Appeals, Rules 104-06 (1957) [hereinafter cited as OHio Rules]. 
of lot valuations, and policies geared to ability to pay or adequate standards of upkeep are reflected in building assessments. For instance, both ability-to-pay criteria and building-upkeep objectives suggest reducing the assessments of large but unfashionable urban dwellings when they are converted to lowerincome housing uses. But in an area undergoing transformation from residential to economically more productive employment, the undesirability of nonconforming uses and the potential increased return to the community from new uses would indicate imposing high assessments to accelerate the change. The separate assessment of land and improvements could automatically harmonize these antithetical policies without the interposition of an assessor's independent judgment. Moreover, since the reproduction-cost approach is inapplicable to land, separate valuation would enable administrators to utilize the most practical methods for simultaneously yet equitably assessing all buildings and lots.

The rules and regulations in all jurisdictions retain in substance previous administrative and judicial tax-distribution policies. The subsidization of lowprofit buildings is continued by permitting the diminution of depreciated reproduction cost to reflect economic and functional obsolescence. ${ }^{122}$ Likewise, extremely profitable specialities are not penalized because "reverse obsolescence" need not receive recognition, and depreciated reproduction cost represents a ceiling on assessments. ${ }^{123}$ Varying effect is accorded the normal-market doctrine, but, in all cases, limits on local taxing and borrowing are imposed. Wyoming has established 1938-1939 as the normal period for construction costs and requires assessment at sixty per cent of computed cost. ${ }^{124}$ Arkansas, contemplating frequent revision, has promulgated cost tables based on current prices, but limits assessments to twenty per cent of computed value pending the adoption of budgetary controls. ${ }^{125}$ The Maryland regulations require assessors to ignore price inflation, and suggest an assessment ratio of fifty per cent of current market price. ${ }^{126}$ Ohio specifies the date-currently 1956-as of which local assessors are to calculate costs. But state authorities retain control over

122. ARK. ManUal 73 ("By capitalization of income, it is possible to arrive at an indicated value of commercial properties"); Md. Instructions 1 (c) ("the following factors are to be considered: ... (2) Reproduction cost less depreciation and/or obsolescence; and (3) -In the case of rental or commercial properties a fair and reasonable capitalization of incone"); Oнxo Rules 107 (providing for functional and economic obsolescence); Letter from Director, Ad Valorem Tax Department, Wyoming Board of Equalization, to the Yale Law Journal, June 12, 1958, on file in Yale Law Library (assessors may use their judgment and modify valuations in individual cases).

123. See text at notes 72-75 supra.

124. Letter from Director, Ad Valorem Tax Department, Wyoming Board of Equalization, to the Yale Law Journal, June 5, 1958, on file in Yale Law Library. Wyoming's tax limits are doubly dependent on assessment ratios since, as valuations rise, the maximum rate falls. Wyo. Comp. Stat. Ann. \$§ 32-201 to -208 (Supp. 1957).

125. Ark. Acts 1955 , act $153, \S 4$, at 362 . Arkansas currently has conventional taxrate limits. ARK. STAT. ANN. \$\$ 84-302 to -304 (1947).

126. Md. Instructions $\S 3$. Maryland has no overall tax-rate limit, but individual limits have been established for most localities either by the state legislature or by the 
the ratio of assessed to computed value and therefore can offset any increase in assessments. Furthermore, such increases are automatically compensated for by the reduction of any tax rate which a local vote had authorized in excess of the statutory limit. ${ }^{127}$

The rules-and-regulations statutes have attacked only the grossest manifestations of regressivity and have left undisturbed its underlying causes. True, increased central supervision, together with improved technical procedures, should correct the tendency of local administrators to assess cheap properties more stringently than expensive ones, and should help bring everyone's realty taxes into the same proportional relationship with the worth of his property. A tax's regressivity, however, is measured not by the relationship of the amount exacted to the worth of the taxpayer's property, but by the relationship of the amount exacted to the taxpayer's income. ${ }^{128}$ Even under ideal assessment conditions, taxes on residences fall more heavily on lower than higher income groups because the former spend a greater proportion of their budgets for housing. ${ }^{120}$ Analogously, obsolescence allowances granted to a business adjust its property taxes to conform with the income of the business and not necessarily with the income of those who pay the taxes, for, ultimately, taxes on commercial entities are usually paid by individuals whose income is not identical with that of the taxed enterprise. The tax legally imposed on a farm, factory, store or rented dwelling, for instance, will eventually be paid, economically, in higher prices charged customers or tenants, in reduced earnings by materialmen, employees, and lenders, or in lower profits for the owners. ${ }^{130}$ So long as rules-and-regula-

municipalities themselves under home rule powers. MD. CoNsT. art. XI-E, $\S 5$; Letter from Director, Maryland Department of Legislative Reference, to the Yale Law Journal, Oct. 10, 1958, on file in the Yale Law Library.

127. Ohio Rules 100, 106(A); Ohio Rev. Code AnN. $\$ \$ 5705.02, .07,5713.11$ (Page Supp. 1958).

128. See text at note 16 supra.

129. See Morton, Housing Taxation 42-45, 60-73 (1955).

130. The process by which the person legally liable for a tax recovers tax payments from other contestants in the economic arena is called shifting. Shifting can be accomplished only when economic conditions permit the legal payor of the tax to raise the price he obtains for the goods and services he sells, or to lower the price he pays for the goods and services, including labor and the use of money, which he buys. See generally Allen \& Brownlee, Economics of Public Finance 215-16 (1947); Seligacan, The Shifting and Ixcidence of Taxation 1-15 (5th ed. 1926).

In all cases, for shifting to be possible enough consumers (or suppliers) must be sufficiently eager to buy (or sell) to allow the producer to raise his price (or cut his costs) without affecting the volume he can sell (or buy) so drastically as to lose more profit than he gains. Allei \& Brownlex, op. cit. supra at 216, 225-27; TAyloR, The Econonics of Public Finance 287 (rev. ed. 1953). But such eagerness alone does not allow shifting. By the hypothesis of economists, the price before imposition of the tax will be set at that point which maximizes profits. See Samuesson, Economics 502-06 (2d ed. 1951). Therefore, even given such a consumption (or production) pattern, shifting will not occur unless the imposition of the tax, by changing the producer's cost pattern, makes another pricevolume combination more profitable, TAYLOR, op. cit. supra at 267-75, 281-87; or unless the imposition increases the quantity that can be sold at a given level of price, see VoN 
tions statutes establish criteria derived solely from the qualities of property owned and without regard to the identity or income of those who actually pay the tax, the perpetuation of current regressive effects is inevitable.

The legislative failure to remedy regressivity is understandable in view of the statistical and theoretical difficulty of identifying actual, ultimate taxpayers. $^{131}$ Only the owner-occupants of residential properties may be certain bearers of the tax; they ordinarily do not shift it because their relations with

Mering, The Shifting and Incidence of Taxation 92-94 (1942). The former change can occur when the tax imposed is such that the producer can reduce his tax liability by reducing his production. Shifting is possible under the latter explanation when the taxin addition to being imposed on the producer in question-is imposed in a shiftable form on the producer of a competing good. Then, the tax, by raising the price of competing products, increases the price consumers may be willing to pay for the product in question.

Thus, entrepreneurs contemplating the construction of buildings for leasing probably take realty taxes into consideration in determining at what level rents should be set. If the market is such that the indicated rents cannot be obtained, the project will be abandoned. Since some prospective tenants will be willing to pay more for new quarters than other prospective tenants, the abandonment of some projects will allow higher rentals on the remaining ones. On the other hand, the builder may cut costs and produce a less expensive, less highly taxed building to rent at an undiminished rent; the consumer will thus receive less for his money. A third possibility, however, is that the alternative of no profit may induce some builders to accept lower rents and hence to absorb some of the tax. The most likely net result will be that the tax, to the extent that it is not avoided by the abandonment of building plans or the substitution of cheaper construction at lower rents, will be borne by the tenant.

Such direct shifting is impossible in the case of existing structures. A tax increase is unlikely to result in buildings being withdrawn from the market. Withdrawal can reduce the tax imposed only if accompanied by the demolition of the improvement or the abandonment of the property for taxes. Moreover, many of the other costs of building ownership, notably interest on mortgage debt and insurance, continue unaffected by vacancy. E. MI. Fisher, Urban Real Estate Markets, Characteristics and Financing 103 (1951). The fact that the landlords of existing structures pay higher taxes cannot, in itself, therefore, lead to higher rents. See SELIGNaN, op. cit. supra at 287-89. But see Morton, Housing Taxation 112-15 (1955).

Existing structures compete for tenants not only among themselves but also with new structures, however. To the extent that a tax increase is reflected in a reduced quantity of, and a higher price for, new rental accommodations, landlords of existing structures will be enabled to raise rentals (or, equivalently, to diminish services) without inducing tenants to move to the new structures. Those owners thereby recover at least part of the added tax. See generally Von MERING, op. cit. supre at 158-70.

Finally, it must be noted that taxes will have effects beyond the limited shifting here discussed. Windfall or intended benefits may accrue to tax-free producers whose competitors are taxed. Continued tax discrimination may lead to shifts of consumer preference toward or away from certain products. Increasing or decreasing total taxes may affect total disposable income and hence the level as well as the pattern of consumption, production, and investment. And government spending of tax revenues will of course have its own varied and far reaching effects. See generally Musgrave, Carroll, Cook \& Frane, Distribution of Tax Paynents by Income Groups: A Case Study for 1948, 4 NaT'L TAX J. 1, 5-8 (1951).

131. The most recent large-scale attempt to assess the incidence of property taxation is found in a study attempting to allocate the nation's total tax burden by income class, 
sellers and lenders are fixed at the time of purchase, and vendees can rarely obtain price discounts representing capitalized future tax payments. ${ }^{132}$ Thether taxes on rental property (business or residential) are borne by landlords or tenants depends upon conditions in the real estate market, ${ }^{133}$ the relative

and to determine the net progressivity of all taxes. The study was conducted by Professor Richard A. Musgrave of the University of Michigan, and was challenged on many grounds, including the allocation of realty tax load, by Dr. Rufus S. Tucker, a General Motors economist.

\begin{tabular}{|c|c|c|c|c|}
\hline \multirow{3}{*}{ Tax on } & \multicolumn{2}{|c|}{$\begin{array}{l}\text { Musgrave's Estimates } \\
\text { Proportion Borne By }\end{array}$} & \multicolumn{2}{|c|}{$\begin{array}{c}\text { Tucker's Estimates } \\
\text { Proportion Bome By }\end{array}$} \\
\hline & & Tenants or & & Tenants or \\
\hline & Ozoners & Customers & Owmers & Customers \\
\hline Owner-occupied Dwellings* & all & none & all & none \\
\hline Leased Residences* & $1 / 3$ & $2 / 3$ & $1 / 2$ & $1 / 2$ \\
\hline Business Property* & $1 / 3$ & $2 / 3$ & $3 / 4$ & $1 / 4$ \\
\hline Farms* & $2 / 3$ & $1 / 3$ & $5 / 6$ & $1 / 6$ \\
\hline
\end{tabular}

*Including land.

Musgrave, Carroll, Cook \& Frane, Distribution of Tax Payments by Inconte Groups: A Case Study for 1948, 4 NaT'L Tax J. 1, 22-23 (1951) ; Tucker, Distribution of Tax Burdens in 1948, 4 NAT'L TAX J. 269, 278-80 (1951).

Musgrave's summation of the ensuing dispute was:

Dr. Tucker limits shifting of the tax on improvements [excluding land] to one-half in the case of farms, three-eighths in the case of business, and three-quarters in the case of rental property. Our assumption had been that the entire tax on improvements is shifted. It is a matter of judgment as to which assumption is more nearly correct.... In the absence of empirical studies, Dr. Tucker is entitled to his assumption, however, as we are to ours.

Musgrave \& Frane, Rejoinder to Dr. Tucker, 5 NAT'L TAX J. 15, 27 (1952).

132. Some shifting of future tax burdens may be possible at the time that an owneroccupied house is purchased. To the extent that property taxes are taken into consideration when buying a house, they will reduce amounts which purchasers are willing to spend and thus cause a decline in the price of homes. The extent of this decline for a given home will represent a recovery by the purchaser of expected future tax payments. See SeligMan, Incidence of Taxation 221-26 (3d ed. 1910); Taylor, The Economics of Public FiNANCE 264-67 (rev. ed. 1953). Shifting at time of purchase-capitalization-probably occurs rarely in the case of houses purchased for owner occupancy, since prospective homeowners are unlikely to give tax considerations much weight. In fact, high taxes may reflect extensive community services which enhance the marketability of residences, and the downward pressure which taxes exert on prices may be offset by the demand for such services.

133. The real estate market is particularly subject to cyclical variations. While a downswing in business may very well bring building to a complete halt, it will not, unless so long-lasting as to result in buildings being allowed to go to ruin, significantly reduce the physical inventory of available structures. A depression does, however-because of business failures, retrenchments, doubling up and postponement of family formation-drastically reduce the demand for accommodations, both business and residential. The resultant oversupply produces a buyers' market in which fandlords are unlikely to be able to raise rents to recoup tax increases. The inability of owners to meet operating costs will not reduce supply, since existing structures will then pass by foreclosure either to mortgagees 
bargaining positions of lessors and lessees, and the importance that they attach to tax considerations..$^{134}$ These questions are further complicated by the facts that each realty parcel constitutes a unique and separate "market," buyers, sellers, landlords and tenants may be amateurs, and the integrating influence of a public exchange or price-setting producer is lacking. ${ }^{135}$ Needless to say, this extreme fractionization of the real estate market prevents legislatures from predicting the incidence of the realty tax on any group. Even if the market's vagaries were susceptible of comprehension, ultimate tax burdens would be clarified only with respect to the occupants of purchased or leased residential property, ${ }^{136}$ and not with respect to business occupants. The latter taxpayers, whether owners or tenants, might still shift their taxes to customers or sup-

or taxing authorities, either of whom will be likely to keep the property on the market to minimize losses, even if gains are impossible. E. M. FISHER, op. cit. supra note 130 , at $102-09$.

Conversely, a boom is likely to result in a prolonged state of undersupply. Despite demands for accommodations on the part of expanding businesses and more numerous, larger and more prosperous families, builders will be inhibited by fears that the demand may be temporary and the risks long-term, by inevitable delays in preparing new land or clearing old land for new construction, and by limitations on the capacity of lenders and the building industry. Under such conditions of shortage, shifting would be impossible, since the reservoir of unfilled demand means that new construction would probably continue unabated even if taxes were increased. E. M. FISHER, op. cit. supra note 130, at 98-100. If the shortage produced rent controls, the possibility of shifting would depend on whether or not increased costs were automatically followed by the allowance of rent increases. N.Y. Unconsol. Laws $\$ 8584(4)$; E. M. FISHER, op. cit. supra note 130, at 109-117.

134. Even with respect to business participants in realty transactions, the multiplicity of factors affecting purchase and rental decisions is likely to relegate conjectures about future realty tax levels to a fairly minor role. See WeIMER \& Hoyt 463-67. Compare WendT 287-90; Garwood, Taxes and Industrial Location, 5 NAT'L TAX J. 365 (1952).

135. E. M. Fisher, op. cit. supra note 130 at 12 . Fisher lists among other elements contributing to the fractionization of the real estate market the permanent nature of realty, the perishability and localization of the services derived from land and improvements, the difficulty of comparing the services rendered by different parcels, the constant fluctuations in consumer standards, and the inflexibility of supply and the variability of demand. Id. at 4-12.

Information about realty prices is particularly elusive. True, local newspapers usually list realty transactions, and commercial reporting services make similar information available to the real estate trade. See Townsend, Inequalities of Residential Property Taxation in Metropolitan Boston, 4 NAT'L TAX J. 361 n.2 (1951). But the conventions of conveyancing frequently conceal the actual considerations paid for real estate. FrIEDMAN, Contracts and Conveyances of Real Property $\$ 86$ (1954); Ballantine, Preparation of Contracts and Conveyances 76 (1921). See also Weimer \& Hoyt 262 (listing available sources of information). While actual consideration can be estimated from the face value of federal documentary stamps attached to a given deed, this technique can lead to serious inaccuracies and does not reveal financing terms and other noncash factors in a transaction. Mitchell, Using Sales Data to Measure the Quality of Property Tax Administration, 1 NAT'L TAX J. 330, 335-36 (1948).

136. Since the residential tenant is the ultimate purchaser of his quarters, he cannot shift the burden of a tax-recouping rent increase. 
pliers. ${ }^{137}$ The ideal solution to regressivity must await a greater understanding of tax incidence.

The rules-and-regulations statutes have also failed to systematize the procedures used in determining the amounts by which assessments are reduced for unprofitability. A structure becomes unprofitable as its value decreases either because of the physical toll of time-that is, depreciation-or because of changes in consumer preferences or in ways of doing business-that is, obsolescence. Centrally promulgated rules and regulations measure depreciation by more or less fixed formulas, which relate age to manner of construction and quality of upkeep. ${ }^{138}$ But obsolescence, which registers both uniform shifts in residential and business fashions, and the localized influence of neighborhood changes and industrial activity, does not readily lend itself to cataloguing and computation. Although capitalized income is considered an objective measure of obsolescence by some appraisers, ${ }^{139}$ this approach has not been made mandatory by those who administer the rules-and-regulations statutes. Instead, obsolescence allowances are left to the discretion of the assessors. ${ }^{140}$

To the extent that administrators have discretion to reduce assessments, judicial review is inevitable. Unfortunately, the language of the rules-andregulations acts is so broad that the courts can authorize policies inconsistent with those enunciated by the central administrator. The Wyoming statute, for example, merely paraphrases the constitutional standard of value and instructs

137. See generally Von Mering, The Shifting and Incidence of Taxation (1942); Taylor, Economics of Public Finance 279-81 (1953).

138. See Ark. Manuad 73, 89, 99, 109, 120,130, 136, 140,143, 178, 180, 182; E. H. BoeckH \& Assoctates, MaNual of Appraisals 305-06 (3d ed. 1937) (used in Maryland). In Wyoming, construction type is ignored and depreciation is computed at $2 \%$ per year up to a maximum of 30 years, subject to individual adjustments. Letter from Director, Ad Valorem Tax Department, Wyoming Board of Equalization, to the Yale Law Jourital, June 5, 1958, on file in Yale Law Library. Ohio lists the factors to be considered but leaves the specific depreciation allowance to the assessor's discretion. OHio Rules 107.

139. For instance, the Boeckh formula directs that, if economic obsolescence is caused by competition from other structures, capitalized income determines value; if it results from a fall in general market conditions, the allowance is one half of the difference between depreciated reproduction cost and capitalized income expressed as a percentage of depreciated reproduction cost. E. H. Boecke \& Associates, Mandal of Appraisals 331-32 (3d. ed. 1937).

140. Although relying primarily on the Boeckh system for "scientific assessment," Wyoming and Maryland have disregarded the Boeckh formula for computing economic obsolescence and permit assessors to exercise personal judgment in allowing for obsolescence. Md. Instructions $\$ 3$ (d) ("After consideration of all the facts, the assessor must then use his best judgment and knowledge of appraisal practices and principles in making a proper assessment") ; Letter from Director, Ad Valorem Tax Department, Wyoming Board of Equalization, to the Yale Law Journal, June 12, 1958, on file in Yale Law Library ("Assessors are permitted to modify valuations in areas such as abandoned coal camps and other similar blighted areas; and also to use their judgment in extreme individual cases"). Similarly, the Arkansas Manual mentions capitalized income, but stresses the judgment of the assessor in applying it. ARK. MANUaL 73. The Ohio assessor's discretion is virtually unlimited. OHIO RuLES 107. 
local assessors to find "fair value" in accordance with the rules promulgated by the State Board of Equalization. ${ }^{141}$ The Wyoming courts are therefore presumably free to prefer local adherence to a judicially conceived measure of value over statewide conformity with the Board's valuation rules. Similarly, the Maryland rules-and-regulations statute carries over an earlier "full cash value" provision. ${ }^{142}$ On its face, the Arkansas act binds the courts to follow

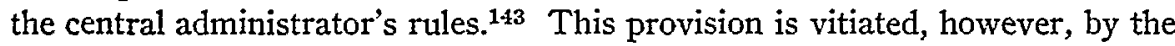
retention of "true market value" in applicable statutes, ${ }^{144}$ by the reiteration of this criterion in administrative regulations, ${ }^{145}$ and by a clause authorizing courts to depart from the administrator's rules whenever uniformity so requires. ${ }^{146}$ Although the Ohio legislature has substituted "taxable value in accordance with the rules . . . promulgated by the board of tax appeals" for "true value," "value" remains in the Ohio constitution, and the statewide administrative regulations assign the task of finding "true value" to the local assessors. ${ }^{147}$

Although no cases have yet defined the scope of judicial review under the rules-and-regulations acts, a 1958 trial court decision in Ohio demonstrates the hostility with which judges are likely to treat statutory reforms limiting assessors' discretion-and, a fortiori, their own. Carney v. Board of Tax Appeals was an action challenging the rules and regulations under Ohio's new act, and the constitutionality of the statute itself. ${ }^{148}$ Section $5703.02(\mathrm{k})$ of the act empowers the state Board of Tax Appeals to adopt "uniform rules and methods for the assessment of real property according to taxable value," and section 5713.01 directs local assessors to "assess all real estate situated in the county at its taxable value in accordance with rules and methods adopted, prescribed and promulgated by the board of tax appeals."149 At trial, section $5703.02(\mathrm{k})$ was held an unconstitutional delegation of legislative power because no stan-

141. Wyo. Comp. Stat. Ann. \$ 32-506 (Supp. 1957).

142. Md. Laws 1954, ch. 72 , at 248 . The "value" provisions were later amended to require an allowance for inflation. MD. CoDE ANN. art. 84, \& 14 (Supp. 1958).

143. Ark. Acts 1955 , act $153, \S 5$, at 362 .

144. ARK. Const. art. 16, § 5; ARK. Stat. AnN. § 84-428 (1947).

145. The statutory basis of assessment valuation ... is true market value.

Market value entails an analysis of all the factors that enter into a transaction arising from the use of property, intelligence and interest of the purchaser and buyer [sic], time involved, and compulsive characteristics.

\section{Ark. Mlanual 6.}

146. Ark. Acts 1955 , act $153, \S 5$, at $362-63$. This clause may be necessary to avoid transgressing the fourteenth amendment of the federal constitution. See note 22 supra.

147. Onio Rev. Code Ans. § 5713.01 (Page 1958); Ohio Const. art. 12, § 2; Ohio RULES 100.

148. No. 200038, Ct. C.P., Franklin County, Ohio, March 29, 1958.

149. Ohio Rev. Code AnN. \$§ 5713.01, 5703.02(k) (Page Supp. 1958).

The rules adopted by the Board of Tax Appeals provide:

Rule 100.

The term "taxable value" means such percentage of "true value" as the Board 
dards were provided for defining "taxable value." The court also held that the Board's rule 100-defining "taxable value" as "such percentage of true value as the Board of Tax Appeals shall determine"-usurped the assessor's section 5713.01 power to assess. ${ }^{150}$

Carney is important not for its constitutional ruling-which is curable through careful legislative redrafting-but for the court's understanding of who, in the nature of things, must exercise ultimate discretion in determining "taxable value." The opinion construes the word "assess" in section 5713.01 to require that the assessor, rather than the Board, make the final decision as to "taxable value." The rules which directed that a "scientific assessment" system be used were deemed not to foreclose the assessor's discretion, for, the decision implies, he retains the authority to conform the results of "scientific assessment" to his own notions of proper assessment. ${ }^{151}$ According to the court, the Board would usurp the assessor's power because it would not establish the taxable percent-

of Tax Appeals shall determine, from time to time ... as to all taxable real property.

The "true value" of real property, as here used, means the value to be determined, in the first instance, by the county auditor [assessor] . . . on consideration of all the facts relating to the [value of the property]. . . .

The county auditor shall not be concerned with "taxable value" until such time as the Board of Tax Appeals shall determine the percentage of "true value" usable for a given period.

Rule 101 establishes the day on which tax liens attach, and directs separate appraisals of land and improvements.

Rule 102 deals with the appointment of assistant assessors.

Rule 103 requires the preparation of maps showing all land holdings, and of schedules and tables used in "scientific" land assessment.

Rule 104 establishes record-keeping and classification procedures.

Rule 105 lays down the general instruction that "all land shall be appraised on the basis of its actual worth or value as of tax lien date of the year in which appraisal is made," and outlines procedures to be used for rural and urban land.

Rule 106 requires the preparation of cost tables based on "prices prevailing during January, 1956" to be used in the valuing of buildings.

Rule 107 lists factors to be considered in allowing for depreciation and obsolescence.

Rule 108 sets January 1, 1959, as the effective date for the rules.

Rule 109 provides interim rules for 1958 valuations. Oнно Rules 100-09.

150. "Here, under the rules of its own adoption the Board of Tax Appeals, and not the Auditor [assessor] as the statute provides, assumes to determine the taxable value of real estate...." Carney v. Board of Tax Appeals, No. 200038, Ct. C.P., Franklin County, Ohio, March 29, 1958.

151. [Under the rules] the same basis for inequalities of valuations which are claimed to have existed because of variations in appraisals in the different counties, would continue as before, since the actual basis of taxation is the same, namely, the true value as determined by the several auditors [assessors].

Carney v. Board of Tax Appeals, supra note 150.

Under the rules, the assessors are required to consider "every . . applicable factor which may tend to indicate the value the property." O\#ro Rules 100 . Specifically, in valuing agricultural land, the county assessor is directed to weigh the facts that the farm is "the homestead of the agriculturalist and his family," and that "farm income is, in 
age of "true value" until after the assessor had completed his computations, ${ }^{152}$ and final determination of taxable amount would therefore remain in the Board. ${ }^{153}$ Presumably, however, the actual date of establishing the ratio of taxable to true value would have been considered irrelevant if the "scientific assessment" rules had been viewed as sufficiently precise to eliminate the assessor's discretion in computing "true value"; the rules themselves would then fall short of the court's standards. ${ }^{154}$ The court's opinion in effect analogizes the Board's control over assessors to an appellate court's mandamus power over lower courts. ${ }^{155}$ The Board was restricted to enumerating significant factors which assessors must consider, but was forbidden to ordain particular results.

\section{A Proposal for Further Reform}

Future realty tax reform should be fourfold. Basic assessment policy must be legislatively, rather than judicially or administratively, determined. ${ }^{150}$ The tax should be made less regressive. Similarly situated taxpayers should be uniformly treated, and all taxpayers should be apprised of existing policy and

the main, dependent upon the farmer's physical effort" and "business acumen." OHro Rules $105(B)$. In valuing commercial property, the assessor is "directed . . . to reflect the income factor . . . in any uniform, logical way that he may see fit." OHro Rures 106(C).

152. [T] . Board ... proceeded to define taxable value as the value it itself should determine by selecting a percentage of the true value which the Auditor [assessor] had found after a compliance with the statutory provisions.

The net result of all this is that the Auditor makes his appraisal in exactly the same manner as before and determines the true value of all real property and according to Rule 100 above noted, is "not concerned with taxable value until such time as the Board of Tax Appeals shall determine the percentage of true value usable for a given period."

Carney v. Board of Tax Appeals, No. 200038, Ct. C.P., Franklin County, Ohio, March 29, 1958.

The rules themselves are unclear as to the timing of the various steps; but the Board did not intend, and the court did not expect it, to set the "taxable value" ratio until the "true values" were established. Letter from the Ohio Board of Tax Appeals to the Yale Law Journal, Sept. 18, 1958, on file in Yale Law Library.

153. The Board's control over the final result is repeatedly denounced by the court. "Thus it would seem that in reality it is the Board of Tax Appeals that determines the 'Taxable Value' rather than the County Auditor . . . "Here, under rules of its own adoption, the Board of Tax Appeals, and not the Auditor as the statute provides, assumes to determine the taxable value of real estate ...." Carney v. Board of Tax Appeals, supra note 152 .

154. The Ohio court's insistence on preserving the assessor's independent judgment is not unique. See cases cited note 63 supra; cf. Zangerle v. Evatt, 139 Ohio St. 563, 41 N.E.2d 369 (1942). But see People ex rel. Village of Park Forest v. Cullerton, 13 Ill. 2d 575,150 N.E.2d 589 (1958) (enforcing local assessment rule).

155. For the mandamus power, see Jewell v. Davies, 192 F.2d 670, 673 (1951), cert. denied, 343 U.S. 904 (1952) (collecting cases).

156. See New Jersey Conm'n on State Tax Policy, The General Property Tax IN NEW JERSEY at xi-xii (6th Rep. 1953). But see note 115 supra. 
be able to secure policy enforcement. Finally, the regulation of municipal spending power should be dissociated from the control of assessment levels.

\section{Restoration of Legislative Policy Making}

Legislatures can resume command of realty tax policy only by rejecting the fiction that the mere incantation of "value" assures that assessments will properly distribute the overall tax burden. The outright abandonment of value as a tax base is precluded, however, by the lack of a workable, equitable and acceptable alternative. Although taxes could theoretically be geared to the varying desirability of land uses, the development of a comprehensive schedule of uses and corresponding tax rates would be impractical. Equally unsatisfactory would be the substitution of original construction costs (even if they could be accurately determined), for this approach would impose penalties on those who buy in booms and confer preferences on those who buy in depressions. ${ }^{107}$ Moreover, to adopt a standard other than value would be to forfeit the public's acceptance of that standard as a reasonable tax base. Consequently, legislatures must retain "value" in their realty tax laws, but must recognize that a statute providing for assessment according to "value" is no more self-executing than would be the Internal Revenue Code were it merely to levy a $\operatorname{tax}$ on "income."158

Realty tax legislation must define taxable value with the same precision that the federal code defines taxable income. As a starting point, an established and proved distinction should be adopted. An improvement's value should be defined as its depreciated reproduction cost, and land values should be based on market comparisons. These techniques are widely accepted by assessors, can be routinely applied to a great variety of properties, rest on economic and commercial assumptions which are readily standardized, and produce figures which can be verified by taxpayers and central administrators. The legislature must also recognize and explicitly provide for those aspects of its land-use and tax policies which require deviations from standard assessment procedures. As

157. See 1 BonBRIGHT 459 ; cf. Sullivan, Administrative Procedure and the Advocatory Process in Urban Redevelopment, 45 CALIF. L. Rev. 134, 137 (1957) (costs of providing required local services suggested as the basis of taxation). For a discussion of the difficulties in allocating service costs, see Barnes \& Raymond, The Fiscal Approach to Land Use Plaming, $21 \mathrm{~J}$. A Arerican Institute of Planners 71 (1955).

Ironically, the prevalence of year-to-year roll copying may in fact result in this sort of assessment pattern under present laws. See NEw Jersey Comar' on StaTE TAX PolICY, op. cit. supra note 156, at 114-20.

158. The Internal Revenue Code devotes thirty-one sections to defining "income." INT. REv. CODE OF 1954, \$\$ 61-121. Thus, early troublesome questions concerning the taxability of stock dividends, the appropriate allowance for a return of capital in mining operations, and the treatment of gains which accrue to the lessor when a leasehold is forfeited, no longer plague courts and confuse taxpayers, but are now statutorily settled. Compare Eisner v. Macomber, 252 U.S. 189 (1920), Stanton v. Baltic Mining Co., 240 U.S. 103 (1916), and Helvering v. Bruun, 309 U.S. 461 (1940), with INT. REv. CoDE of 1954, $\S \S 305-07,611-14,109$. 
a result, the judiciary would be largely limited to correcting deliberate deviations from legislatively prescribed assessment systems. ${ }^{159}$ Litigation could be further reduced by the publication of clear and detailed administrative regulations, which would afford taxpayers an expeditious means of corroborating the accuracy of assessments. ${ }^{100}$ Such regulations would combine with the legislature's own specificity to deprive local assessors of their present wide discretion, for their ministerial acts could then be scrutinized by state officials and individual taxpayers.

In defining "value," legislatures need not go so far as to assign precise dollar amounts to the different characteristics of realty which an assessor evaluates in making an appraisal. Rather, legislation should enumerate all those characteristics from which assessments may be derived, should detail procedures and methods for computing the dollar amounts assignable to each characteristic, and should direct a central administrator to prepare a catalogue of dollar amounts for every enumerated characteristic. Under legislation of this sort, local assessors would merely record observable facts-the presence or absence of the enumerated characteristics in each parcel. The assessor would be required to assign each such characteristic, if present, its specified value, and to ignore unenumerated factors. The actual mathematical computation of value could then be made by automatic computing devices. Admittedly, this concentration of decision-making in the legislature would invite high-powered lobbying. But local assessors currently respond to more circumspect pressures, and the enactment of valuation formulas by the legislature would shift the locus of taxing authority to a more politically responsible body.

\section{Basic Valuations Under the Proposed System}

Improvements. The first task of a legislature which follows the suggested approach would be to specify those factors critical to determining the reproduction cost of improvements. Probably the most important factors which affect the cost of constructing, and hence the cost of reproducing, a given building are its intended function, its size, and the materials of which it is made. To

159. The tax provisions in state constitutions would have to be amended to prevent the judicial review of assessments in "value" terms not found in the reformed statute and regulations. See text at notes $205-09_{0}$ infra. The fourteenth amendment and its state constitutional counterparts would also remain as potential sources of judicial legislation. Reasonable distinctions among taxpayers have long been upheld, however, and judicial challenges to reform are likely to be limited to ascertaining the reasonableness of the new tax structure, and are unlikely to review its effect in particular cases. See 1 COOLEY, TAXATION $\$ 332$ (4th ed. 1924) (collecting cases).

160. Although detailed standards would probably increase the volume of taxpayerassessor disputes, controversies would be framed in factual terms, and informal consultations or formal administrative review would be likely to settle most cases. In any event, litigation would require judicial fact-finding, or the construction of regulations, rather than determinations of "value." See Daniels v. Board of Review, 243 Iowa 405, 423-24, 52 N.W.2d 1, 11-12 (1952) (appeal based, inter alia, on allegation that buildings were not in existence on assessment day). 
provide for differences in function, a legislature should establish building iclassifications in terms of building uses. Major categories would include residential, manufacturing, commercial, office, entertainment, and farm structures. A special category should be created for unique construction. ${ }^{101}$ Buildings designed for multiple uses would fall under more than one category. Major categories should be further divided into subtypes like single-family, two-family or multifamily residences, or heavy, medium or light manufacturing plants. The central tax authority should then be directed to compile a schedule showing the cost of reproducing representative buildings in each subcategory, different costs being provided for variations in size and construction materials. The legislature should also specify construction features which significantly affect cost, such as basements and fixtures, and types of partitions, floors, ceilings and roofing; and should direct the central tax authority to prepare tables showing the cost added or avoided by variations in these items. Moreover, since costs of construction would doubtless vary throughout the state, model legislation should direct the central administrator to divide the state into areas corresponding to the principal patterns of construction costs, and to compensate for interarea differentials in his schedules. ${ }^{162}$ Finally and above all, the central administrator should be directed to rely only on average construction costs, and not to permit the cost of a particular building to enter into the process of calculating its assessment.

Abandoning the search for "true value" would also make possible the utilization of centrally prepared depreciation tables. Under a "true value" system, to find an actual decline in utility because of a given structure's age requires the subjective evaluation of its state of repairs, and speculation as to its useful life. ${ }^{163}$ By way of contrast, under the proposed system, depreciation allowances could be treated as they are in the Internal Revenue Code, with the rate of depreciation based on average, rather than actual, declines in value. ${ }^{104}$ Likewise.

161. Unique construction could be assessed directly by the central administrator.

162. Compare ARK. MANual 70-71 (dividing state into seven residential-constructioncost areas).

163. All physical depreciation tables are recommended depreciations under average conditions. Superior maintenance and below average maintenance are some of the many factors that must be recognized as a reason for variance from the recommended percentages. Remodelling is another factor of age recovery that the Assessor must recognize and allow for . ... Extreme care and judgment must be exercised Id. at 73. in correcting depreciation for age recovery.

164. Present income tax policy allows taxpayers to use any one of four accounting conventions as to depreciation rates, and to assume any reasonable life span. Taxpayer manipulations are avoided by a requirement of consistency. INr. Rev. CODE of 1954, \& 167. Regulations establishing building life expectancies and depreciation rates are now regarded as informative only. 2 CCH 1958 Stand. Fed. TAX Rep. TI 1777.288, 299.

Similarly, under the British system of local taxation based on annual proceeds, fixed allowances are provided to convert gross into net income. See Local Government Act, 1948,11 \& 12 Geo. 6, c. 26, \$ 83; Rating and Valuation Act, 1928, 18 \& 19 Geo. 5, c. \$, \$ 1 ; Rating and Valuation Act, 1925, $15 \& 16$ Geo. 5, c. 90, § 2. See also Harris, The British Revaluation of Real Estate for Local Taxation, 5 NAT'L TAX J. 239 (1952). 
special depreciation schedules might reduce taxes on favored activities. Generally, depreciation schedules should make no provision for the condition of individual improvements and should thereby reward maintenance-conscious owners while penalizing the irresponsible. To encourage modernization, remodeling could be depreciated from the date a building was originally erected. A maximum ratio of depreciated cost to annual repair should be established, however, to prevent new construction and extensive capital improvements from being disguised as repairs. If the statutory maximum were exceeded, depreciation on the excessive improvements could be computed from their date of completion. Depreciation rates might also be used to stimulate particular construction deemed necessary to the state's economy. ${ }^{165}$ Quick depreciation rates, for instance, could be used to stimulate the construction of low-cost housing, ${ }^{160}$ or the renovation of factories by businesses in financial difficulty. ${ }^{167}$

Administrative discretion-which is preserved under the existing rules-andregulations statutes through obsolescence allowances-could be all but eliminated by isolating, and according special treatment to, the various nonphysical factors which cause declines in value. Provisions for losses resulting from style changes could be incorporated into ordinary depreciation schedules, for the principal elements of architectural obsolescence could be itemized and corresponding deductions specifically authorized. ${ }^{168}$ In this way, economic pressures inducing the over-intensive use of obsolete buildings would be reduced. ${ }^{169}$ Outmoded realty is often structurally sound but incapable of commanding the high actual or imputed rents necessitated by the taxes resulting from rigid assessment practices. Such rigidity fosters overoccupancy, inadequate maintenance, and conversion to nonconforming uses. On the other hand, depreciation schedules which account for architectural obsolescence would subserve sound land-use policy.

Obsolescence reflecting the diminished prosperity of particular industries to which structures are specially adapted should not be included in depreciation schedules. Rather, legislators should decide on its own merits the question of whether this type of tax concession ought to be granted in order to preserve failing enterprises, or denied in order to allow free rein to economic natural selection. If tax relief is accorded, it should not take the form of obsolescence deductions but should be integrated into a progran of reduced realty taxation for unprofitable businesses. ${ }^{170}$

The remaining cause of obsolescence, neighborhood change, is best treated

165. See, e.g., INT. Rev. CoDE of 1954, $\S 168,169,174$ (quick depreciation for emergency facilities, grain storage facilitie's and research investments).

166. See note 104 supra.

167. See cases cited note 83 supra.

168. Cf. Bailey, Estinating Accrued Depreciation of Office Buildings, 26 ApPRAISAL J. 270 (1958).

169. Some cities have attacked this problem effectively through building and housing codes. See Colean, Renewing Our Cities $45-46$ (1953).

170. See text at notes 197-204 infra. 
as a component of land value. Obsolescence of this sort occurs when, for example, commercial encroachments into residential areas lower the value of residential improvements. At the same time, the value of land usable for further commercial development increases. In this situation, taxing authorities can either maintain high residential assessments, thus diverting funds needed for repairs ; or reduce residential valuations, thus reflecting the area's diminished desirability and bring taxes into partial conformity with the owners' ability to pay; or increase assessments, thus recognizing the land's added attractiveness for commercial use and encouraging the change. ${ }^{171}$ Once the legislature has selected one of these goals, property values can be computed accordingly.

Land. The assessment of land is less amenable to central control than is the assessment of buildings, because only extremely localized market data are appropriate for its valuation. The primordial nature of land renders the computation of its reproduction cost impossible. ${ }^{172}$ Furthermore, difficulties in allocating income between land and improvements make the income capitalization of the former impractical. ${ }^{173}$ Therefore, an analysis of sales prices must form the basis of land valuation under the proposed system. The principal variables affecting the appraisal of land are its location, physical features and projected uses. These may be further broken down into the influences of surrounding demographic patterns, zoning ordinances, and housing and building codes; the

171. These alternatives may be illustrated as follows.

Assume:

Depreciated reproduction cost of building; no allowance for neighburhood . $\$ 4,040$

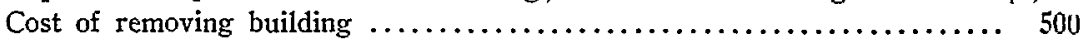

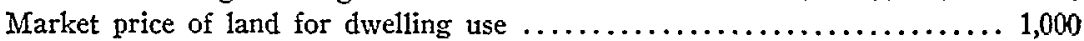

Market price of land for commercial use $\ldots \ldots \ldots \ldots \ldots \ldots \ldots \ldots \ldots \ldots, 0, \ldots \ldots$

The valuation possibilities are then:

a. Value for residential use ................. $\$ 4,000+\$ 1,000=\$ 5,000$

b. Value for commercial use ............... $\$ 6,000-\$ 500=\$ 5,500$

c. Maximum assessment .................. $\$ 4,000+\$ 6,000=\$ 10,000$.

Standard commercial appraisal policy is to use formula (a) or (b), whichever produces the greater valuation. Stated differently, the land is valued for residential use until the commercial use value of the land exceeds the residential use value of the land and building: combined. This, of course, reflects the point at which economic motivation would result in a use change. Interview with Norman R. Penedict, M.I.A., Hamden, Conn., June 5, 1958. Since the legislature may seek to control, rather than reflect, economic forces which affect land use, it is free to adopt any of the three formulas.

172. See Wagner, Appraisal of Single-Family Homes, 26 ApPRAISAL J. 40, 43 (1958).

173. Capitalizing rental income, except in the relatively rare case in which ground rent and building rent are separate charges, will yield the value of the improved parcel rather than the value of the land alone. Commercial appraisers, if required to allocate between land and improvements, normally do so by subtracting the depreciated reproduction cost of the building from the capitalized income value of the improved parcel. See WENDr 174 . Transplanting this approach from its commercial context to tax valuation is possible only if capitalized income is to be the sole measure of taxable value, since directing an assessor to add the depreciated reproduction cost of the building to the capitalized income value of the land, determined as described above, clearly would take him right back to his initial point of departure. See 1 Bonbright 485 n.68. 
proximity of transportation facilities, schools, churches, parks, nuisances and centers of industry and commerce; and the size and shape of the individual lot.174 The foregoing factors are less easily categorized, however, than construction costs and depreciation rates, and thus are less readily translated into uniformly applicable schedules of relevant characteristics and corresponding values. A comparatively large measure of assessor discretion is consequently unavoidable in land valuation. Legislatures can restrict the land assessor's freedom of judgment only through the clear elaboration of policy, an insistence on valuation by stated formulas wherever feasible, and the establishment of stringent procedural, publicity and review requirements.

The clear exposition of land policy is most needed and will prove most useful in localities of changing land use. Where areas are in transition between, for example, farm and residential, residential and commercial, or commercial and industrial uses, assessors currently may value land in accordance with either its present or prospective use. Legislatures should eliminate the assessor's discretion to choose between these alternatives, and should themselves determine, for instance, whether land valuations are to impede commercial encroachments or are to accelerate neighborhood change. ${ }^{\mathbf{1 7 5}}$ Thus, a mandate to assess land as farm acreage until it is actually sold as subdivided building lots would benefit persons holding the land and would exert no pressure to accelerate the process of subdivision. ${ }^{178}$ On the other hand, speculative land-holding and leap-frog development would be discouraged by a legislative requirement that all land in substantially subdivided areas be assessed according to its optimum use consistent with the projected development of the subdivision. ${ }^{177}$ Another, more limited sphere for legislative policy-making is the elimination of nonconforming uses-which might be advanced by assessing the land involved as though it were being used in an optimum, conforming manner. ${ }^{178} \mathrm{~A}$

174. See generally E. M. Fisher, Economic Aspects of Urban Land Use Patterns, 6 J. OF InDUSTRIAL Economics 198 (1958).

175. On the basis of the figures presented in note 171 supra, if the tax rate were $4 \%$, annual tax liability at maximum assessment would be $\$ 180$ more than the liability under the larger of either alternative. Were occupants to bear such a tax increase, they might be encouraged to move to more desirable neighborhoods. Those landlords who are unable to shift such a tax increase to tenants will, because of reduced profits, find conversion to new uses more attractive.

176. For such a mandate, see MD. ANv. CoDE art. 81, § 19(a) (1957). Decreasing the cost of holding lands idle enables speculators to delay sales and to await rises in market value. Cf. Comment, Municipal Real Estate Taxation as an Instrument for Community Plaming, 57 Y ALE L.J. 219, 221-22 (1947). Such speculative holding can be an advantage to a community beset by the demands of a swelling population. See Beach $v$. Planning \& Zoning Comm'n, 141 Conn. 79, 103 A.2d 814 (1954).

177. For such a requirement see Mo. ANN. Code art. 81, § 19 (1957).

178. Thus, if slaughterhouses which had depressed land values in one of the most valuable sections of New York City to $\$ 5$ a foot, and which were held by their owners largely because the acquisition of equivalent facilities within the city was impossible, had been taxed not on the $\$ 5$ per foot basis indicated by sales of nearby land, but on the $\$ 50$ or $\$ 500$ per foot basis that would prevail if the nonconforming use were removed, a change 
less modest goal-the full use of scarce urban land-might be subserved by a quasi-depreciation allowance recognizing the lowered adaptability of improved land. ${ }^{179}$

Were land-use preferences enumerated by the legislature, the assessor's discretion in this respect would be curtailed. Given a policy goal, however, assessors would still have substantial latitude in the actual computation of values. For example, a directive to ignore the higher worth of adjacent commercial property in mixed-use areas would not dictate the value which an assessor should put on a given residentially used lot. No substitute has been developed for informed judgment in land valuation. Nonetheless, two techniques are available for limiting the scope, and uniformly applying the results, of the assessor's subjective valuations. Repeated empirical studies have shown that uniform relationships exist between a lot's size and shape, and its value. These relationships, fundamental to "scientific assessment," can be expressed in terms of standard lots. Thus, according to one study, a lot 150 feet deep is worth fifteen per cent more than a standard 100 foot lot. ${ }^{180}$ And a different sampling revealed that reducing a lot's width from the conventional 50 to 45 feet reduced its value by five per cent. ${ }^{181}$ Detailed schedules have been compiled at various times and places to show the effect on a lot's value of its length, width, shape, and position on the block in which it is located. ${ }^{182} \mathrm{~A}$ tax-law provision requiring the use of tables of this sort, as compiled by the central tax administrator, would limit the assessor's discretionary function to finding the value of a hypothetical standard lot for each significantly distinct area in his jurisdiction.

Value differentials among these standard lots would also tend to fall into patterns. In commercial areas, values are highest at the intersections of major streets. ${ }^{183}$ The most valuable industrial land is concentrated near heavy transportation facilities. ${ }^{184}$ Land's utility for residences and its topography may well

in use would have been encouraged. See Zeckendorf, New Cities for Old, The Atlantic, Nov. 1951, pp. 31, 35. See generally Note, Amortization of Property Uses Not Conforming to Zonting Regulations, 9 U. CHr. L. Rev. 477 (1942).

179. Construction of an improvement involves a calculated risk, in that it makes the site unavailable for possible, more profitable, near-future use. This risk would be reduced if owners were afforded tax reductions commensurate with the durability of the improvement. This allowance might be measured by the cost of making the site available for other uses-the cost of demolition. Compare Comment, Mrunicipal Real Estate Taxation as an Instrument of Community Planning, 57 YALE L.J. 219 (1947).

180. Manufacturer's Appraisal Co., Prospectus of New York Somers System Service 9-11 (undated). See also Zangerie, Principles of Real Estate Appraising 106-13 (2d ed. 1927).

181. E.M. Bozcke \& Associates, Manual of Appraisals 347 (3d ed. 1937). See also National Ass'n of Assessing Officers, URBan Land Appraisal 144-45 (Assessment Practice Series No. 2, 1940). Compare Institute of Public Service, University of Connecticut, Handbook for Connecticut Assessors 19, 104 (1950).

182. See National Ass'n of Assessing Officers, Urban Land Appraisal 58-148 (Assessment Practice Series No. 2, 1940).

183. WhIMER \& Hoyt $446-49$ (3d ed. 1954).

184. See authorities on industrial location cited note 134 supra. 
rise and fall together ${ }^{185}$ The location of the most and least valuable lots in each group of lots can be ascertained from a consensus of expert appraisers. A careful appraisal of such key lots and statistically selected intervening ones would enable assessors to develop formulas yielding standard, per-unit values for all intervening lots. ${ }^{186}$ Adjustments for positional and dimensional deviations from the standard lot could be made by applying the percentages found in the schedules described in the preceding paragraph.

Deriving and modifying standard lot values in this fashion would, however, inadequately reflect many conditions which cannot be systematized but which peculiarly affect individual lot values. A sophisticated realty tax statute would specify the conditions which could justify deviations from per-unit land values. Drainage, pitch, immediate access to transportation arteries, proximity to nuisances, and similar factors might provide the basis for statutorily authorized deviations. Precise allowances of this sort would, in most instances, be discretionary. To prevent an abuse of discretion, the statute might establish the maximum allowance permissible for each authorized factor and for all factors, and the maximum legal differential between allowances granted to different properties which are affected by the same factor and are within the same use group.

Since personal judgments ultimately determine the valuation of key lots and the allowance of additional adjustments, procedural safeguards are essential to an equitable land assessment system. Taxpayers should receive notice of their assessments and opportunities for review. The local assessor should be directed to publish preliminary assessments sufficiently in advance of their becoming final to permit hearings, and to allow for appeals by taxpayers or spending authorities. Publication could take the form of lists of the assessed values of all lots, and maps showing the key lots and the standard value or values for each city block. After the preliminary assessments have been published, the assessors should hold hearings at which the selection of key lots, the values assigned those lots, and the valuation formulas themselves can be contested by interested parties. When assessments become final, revised lists and maps should be prepared and forwarded to the central tax authorities for approval. Alternatively, two distinct stages of notice, hearing, revision and review might be instituted - the first establishing key lots and per-unit values, and the second assigning values to individual lots.

At any time prior to the day on which assessments become final, taxpayers or levying authorities should be permitted to petition local assessors to allow individual lot variances from the assessment pattern. For every variance granted, whether on request or otherwise, the assessor should state in writing his reasons for distinguishing the lot in question from contiguous, formula-

185. See generally Max, The Valuation of Residential Real Estate 86-106 (2d ed. 1956).

186. This method would only require the refinement of present scientific land valuation techniques. See note 62 supra; National Ass'N of Assessing Officers, Urban Land Appraisal 52-58 (Assessment Practice Series No. 2, 1940). 
valued land. His statement should be sent promptly to contiguous land owners, local levying authorities, and the state tax commissioner. The commissioner should have the authority independently to reject or approve all locally allowed variances. Variance requests rejected by local assessors should also be appealable to the state tax commissioner. Judicial review should then extend only to determinations by the commissioner and should be limited to issues of alleged actual fraud or failure to comply with statutory procedures.

\section{Departures from the Basic System}

The suggested system for assessing land and improvements would allow taxpayers to verify their own liability, would sharply curtail the assessor's discretion, and would minimize the need for costly legal action and the occasions for judicial policy-making. Two other problems, regressivity and relief for unprofitable businesses, remain.

Regressivity. Studies of tax incidence must be undertaken before statutory changes designed to render realty taxation less regressive are initiated. ${ }^{187}$ Immediate assistance for the owner-occupiers of residential property is possible, however, for their inability to shift realty taxes is presently demonstrable..$^{188}$ To the extent that such assistance would stimulate the construction of lowcost, single-family units competing with low-rent apartments, the tenants of these apartments could also be benefited. ${ }^{189}$ But the identical treatment of rental and owner-occupied property in this regard would be inappropriate, since benefits intended for tenants would accrue to their landlords whenever the latter were unable to shift realty taxes to the former. ${ }^{190}$ For owner-

187. See text at notes 131-37 supra.

188. See note 132 supra and accompanying text.

189. Cooperative apartments, combining elements of tenant ownership and rental, would present a special case. To the extent that cooperatives are actually run on a "sharethe-costs" basis, they should be treated as owner-occupied, since the incidence of the tax would then be on the cooperators. But to the extent that they are run as businesses by management groups who set maintenance charges in the same manner as other landlords set rents, they should be treated as rental properties. See generally Anderson, Co-operaticc Apartments in Florida: A Legal Analysis, 12 U. Mramr L. Rev. 13 (1957) ; McCullough, Co-operative Apartments in Illinois, 26 CHI.-KeNr L. Rev. 303 (1948).

190. See Burkhead, Property. Tax as a Burden on Shelter, 20 J. LAND \& P.U. EcoN. $255,262-63$ (1944). The burden of the tax or the benefit of an exemption would be shifted only when new construction was an important influence in the market. See note 130 stupra. Shifting therefore would be impossible during bad times when construction was halted or during a period of extreme shortage. See note 133 supra. Moreover, price and prejudice bar large segments of the population from competing for new housing and hence insulate many of the potential victims of regressivity from the realty tax. These qualifications, recognized by economists in evolving their rule that taxes on improvements but not on land are shifted, Von Mering, The Shifting and Incidence of Taxation 161-62 (1942) ; Morton, Housing Taxation 112-15 (1955), although sometimes ignored in stating their legislative recommendations, $i d$. at 192-94, make direct expenditures for lower income housing seem a more efficient use of public funds available for the mitigation of property tax regressivity than the granting of exemptions to owners of rental property. 
occupiers, regressivity can be reduced by graduating tax rates, by adopting assessment criteria which favor cheap construction, or by enacting fixed-sum or graduated exemptions. ${ }^{191}$ The well-known and often-used exemption device seems preferable, because a multiplicity of statutory criteria for different types of construction would be cumbersome, and the mere mention of progressive rates would doubtless arouse unnecessarily intense political opposition..$^{192}$

Exemption provisions must be carefully drawn to prevent excessive revenue losses. The definition of "homestead" found in existing exemption clauses should be abandoned, for the term often embraces income-producing farm and business property. ${ }^{193}$ Correctly drafted, an exemption would be limited to realty used by its owner as a home with assessments being allocated in the case of mixed-use residential property. The amount of exemptions should be limited to the lowest sum consistent with the policy of mitigating regressivity. ${ }^{194}$ Taxation on a broad base should be preserved, and can be reconciled with the goal of progressive taxation by graduating the exemptions. Thus, fifty per cent of the first $\$ 3,000$ of eligible property's assessed valuation, forty per cent

191. See note 15 supra.

192. Graduated tax rates would also be unconstitutional under the uniformity clauses of many state constitutions. See note 19 supra.

193. See, e.g., Fla. Const. art. 10, § 1.; Fla. Stat. Ann. $\$ 192.12$ (1943) (homestead includes 160 acres adjoining rural residence; urban homestead includes house used for business as well as residence). The Florida statute has been held to cover hotels, apartment houses and tourist camps. Crosby \& Miller, Otr Legal Chanteleon, The Florida Homestead Excenption: V, 2 U. FLA. L. REv. 346, 372-75 (1949).

194. Further study is indicated before such exemptions can be calculated. Some indication of the kinds of studies needed and the general results to be expected can be found in available correlations of Wisconsin property and income tax data.

\begin{tabular}{|c|c|c|c|c|c|}
\hline \multirow[b]{3}{*}{$\begin{array}{l}\text { Family In- } \\
\text { come Group }\end{array}$} & \multirow{3}{*}{$\begin{array}{l}\text { Average } \\
\text { Family } \\
\text { Income }\end{array}$} & \multicolumn{4}{|c|}{ Amual Property Tax Payments, Assuming } \\
\hline & & \multicolumn{2}{|c|}{ No Exemption } & \multicolumn{2}{|c|}{$\$ 2,000$ Exemption } \\
\hline & & Amount & $\begin{array}{l}\text { Percentage of } \\
\text { Family Income }\end{array}$ & Amount & $\begin{array}{l}\text { Percentage of } \\
\text { Family Income }\end{array}$ \\
\hline$\$ \quad 0-249$ & $\$ 149$ & $\$ 141$ & $94.63 \%$ & $\$ 88$ & $59.1 \%$ \\
\hline $250-499$ & 374 & 134 & 35.83 & 81 & 21.7 \\
\hline $500-749$ & 637 & 136 & 21.35 & 85 & 13.3 \\
\hline $750-999$ & 884 & 133 & 15.05 & 78 & 8.8 \\
\hline $1,000-1,249$ & 1,128 & 126 & 14.61 & 71. & 6.3 \\
\hline $1,250-1,499$ & 1,391 & 125 & 8.99 & 71 & 5.1. \\
\hline $1,500-1,749$ & 1,625 & 133 & 8.18 & 77 & 4.7 \\
\hline $1,750-1,999$ & 1,871 & 137 & 7.32 & 82 & 4.4 \\
\hline $2,000-2,499$ & 2,223 & 148 & 6.66 & 94 & 4.2 \\
\hline $2,500-2,999$ & 2,732 & 183 & 6.70 & 129 & 4.7 \\
\hline $3,000-3,999$ & 3,436 & 208 & 6.05 & 155 & 4.5 \\
\hline $4,000-4,999$ & 4,459 & 244 & 5.47 & 191 & 4.3 \\
\hline 5,000 and over & 12,743 & 378 & 2.97 & 323 & 2.5 \\
\hline
\end{tabular}

Morton, Housing Taxation 228-29 (1955).

Families receiving an income of less than $\$ 1,000$ almost invariably fall into one of three classes: those on public relief; those whose income for the particular year has been re- 
of the second $\$ 3,000$, and so forth, could be exempted. ${ }^{195}$ Levying authorities, bearing in mind that exemptions inevitably bring revenue reductions unless tax rates are simultaneously raised, should be prepared to enact such increases. In any event, revenue losses should not be recouped by sales taxes or other regressive devises. ${ }^{196}$

Recognition of Business Hardship. The present judicial and administrative manipulation of "value" designed to provide relief for unprofitable enterprises indicates a strongly felt need which, if ignored by future legislation, will invite continued manipulation. The proposed elimination of "value" as the keystone of the assessment system would, however, destroy the theoretical basis of the present distinction between low-"value," or obsolete, and low-"income," or badly managed, properties, ${ }^{197}$ and would leave to the legislatures the formulation of a new rationale for assisting unprofitable businesses. In devising a rationale, a legislature should be guided by the probable effects of possible

duced by losses, but who are very likely sustaining their standard of living from savings; and those receiving a retirement income adequate for their own needs.

Failure to eliminate regressivity as regards the first group is not serious. The number of people in this group owning property is likely to be small, and, in any event, taxing relief recipients merely moves money from one governmental pocket to another. Apparently regressive taxation of the second group-those who are suffering from setbacks and living on capital-is defensible on the theory that until their decline in income is reflected in a decrease in their housing standard of living, sufficient ability to pay exists to warrant the unabated taxation of their homes. As for the last group-pensioners living in a home purchased during their earning years-regressivity could be reduced, and the social interest in the independence of the aged served, by providing additional exemptions to those whose major source of income is retirement income as defined in INT. REv. ConE of $1954, \S 37$.

Similar qualifications are necessary in dealing with the $\$ 5,000$-and-over income bracket. Statistically, this grouping is too large to be meaningful. One or two cases of very large incomes coupled with ownership of only reasonably luxurious homes could overbalance many instances where the ratio of tax to income was close to that in the preceding brackets. For instance, at a $3 \%$ tax rate, property taxes would consume $5 \%$ of the income of a family earning $\$ 6,000$ and owning a $\$ 10,000$ home, while one with a $\$ 100,000$ income and a $\$ 50,000$ home would pay a realty tax amounting to $1.5 \%$ of its income. Bracketing 90 families in the $\$ 6,000$ class with 10 cases in the $\$ 100,000$ groups would produce an average tax payment which would be $2.7 \%$ of the average income. Thus, the mildly regressive trend present up to the $\$ 4,000-4,999$ bracket probably continues to be gradual for some distance beyond. Moreover, while those in the extremely high income brackets do feel the bite of the property tax least, this is perhaps acceptable because of their great income tax load, and inevitable because of their high marginal income tax rates and the deductibility of local tax payments.

Institution of a $\$ 2,000$ exemption would reduce the regressiveness of the realty tax on families in the $\$ 1,000-4,999$ brackets from 9.14 percentage points to 2 percentage points. Further reduction of regressivity, without raising exemptions to prohibitive levels, could be accomplished by allowing an additional exemption limited to low-value property.

195. British income taxation achieves progressivity below the $£ 2,000$ level through graduated exemptions. Finance Act of $1927,17 \& 18$ Geo. 5, c. $10, \S 40$.

196. For a discussion of this problem, see Uta Investigating Comm. of Utah GOVERNMENTAL UNITS, REPORT 84-143 (1936).

197. See text at notes 76-88 supra. 
standards. Were existing rules codified-thus, in effect, preserving the "value""income" dichotomy-tax reductions would be conditioned on the productive use of property within its capabilities, so that new uses of adaptable property would be encouraged, while current uses of sterile property would qualify for tax relief. Of course, any statutory distinction between poorly managed and well-managed-but-obsolete realty would invite litigation. A different approach, suggested by the contemporary subsidization of migrant industries and passenger railroads through reduced assessments, would favor only those enterprises essential to the local community. ${ }^{198}$ Following yet a third approach, a state legislature could adopt the view that business instability is itself an evil to be combated by means of tax devices, and grant relief to all unprofitable undertakings.

Whatever the subsidization policy adopted, it could be given effect by allowing unprofitable businesses within its scope to pay a tax based on an alternative assessment derived from capitalized income. A given business's eligibility for this alternative could be deemed established whenever that portion of the business's annual income allocable to its real property is less than a specified percentage of its assessed valuation arrived at by standard computations. Income to be capitalized should be not estimated future, but actual current, earnings, and capitalization rates should be set not by assessors on a taxpayer-to-taxpayer basis, but by the legislature for the different classes of favored businesses.

Capitalizing income on the basis of actual earnings would gear alternative assessments to demonstrated financial need. The determination and definition of an individual owner's earnings could be accomplished by requiring him to supply a copy of his federal income tax return for the relevant period when applying for an alternative assessment; and by equating current earnings to the federal definition of taxable income. ${ }^{109}$ For firms which have inordinately low income or run deficits, legislation might continue the "salvage value"200 rule and assess improvements at either the highest price obtainable on liquidation or an arbitrary percentage of the normal reproduction-cost assessment.

Utilizing federal income tax returns to define current earnings would not solve all administrative problems attending the computation of the proposed, alternative, capitalized-income assessments. Difficulties would remain in allocating a single firm's income among its branches in various jurisdictions, and between its realty and nonrealty production components. ${ }^{201}$ With respect to interstate

198. See N.Y. Times, June 16, 1958, p. 1, col. 2 (railroad); $i d$. ., July 23, 1958, p. 29, col. 5 (same); notes 83,110 supra (migrant industries).

199. Adoption of federal standards has been suggested and experimentally used as a device for simplifying state and local income tax problems. HaIg \& Shoup, The Financlal Problem of the City of New York 259-65 (1952). Auditing problems can thus be largely shifted to the federal revenue service. Under federal law, local officials are given access to federal returns. See INT. Rev. Code of 1954, § 6103(b); Bureau of Internal Revenue, Exchange of Information for Purposes of Federal, State, and Local Tax Administration, 2 NAT'L TAX J. 151 (1949).

200. See text at note 84 supra.

201. The net income of a firm producing several products is no sure indication of the profitability of a plant producing only one product. Similarly, identical net income earned 
firms, state income and corporate tax laws have resolved the former problem through an arbitrary formula which allocates income according to the local-tototal ratio of sales, payroll disbursements, and fixed-asset values. ${ }^{202} \mathrm{~A}$ similar procedure could be developed for attributing income to each of a firm's plants within a state.

A solution to the second allocation problem-isolating income attributable to the realty factors of production—cannot be achieved with such facility. In appraising profitable specialties, many courts approximate a solution to this problem by establishing depreciated reproduction cost as a ceiling on assessments. ${ }^{203} \mathrm{~A}$ more satisfactory answer may lie in the central preselection of capitalization rates. After studies have been made of the various industries within a state, a statute or regulation could promulgate rates reflecting the proportion of income attributable to real estate in each type of industry. A given rate would not conform exactly to a particular firm's revenue loss, because the allocation between realty and nonrealty would represent average, industry-wide figures, rather than any individual circumstances. As a product of legislative grace, however, this imperfect computation should be no more objectionable than the inflexible dependency deduction of income tax statutes. In any event, the alternative assessment derived from this rate would effect in a uniform, predictable and politically responsible manner tax adjustments which are currently left to the tax assessor's discretion. Furthermore, since, under this system, capitalization rates would also have to be computed for each industry to allow for the risks and managerial costs peculiar to that industry, ${ }^{204}$. these rates could well be combined with those derived for determining the realty-nonrealty ratio. The resulting combined rate would, of course, when multiplied by the actual income attributable to a parcel, yield that parcel's alternative valuation.

\section{Constitutional Amendments}

Insulating legislative tax policy from undue judicial interference will require the amendment of most state constitutions. The language in many constitu-

by a professional man and a farmer, or a manufacturing plant and a parking lot, is composed of very different returns on the components of labor, land and equipment employed.

202. A newly proposed uniform law allocates income according to the arithmetic average of (1) the ratio of the taxpayer's tangible property within the state to his total tangible property; (2) the ratio of the taxpayer's payroll expenditures within the state to his total payroll expenditures; and (3) the ratio of the taxpayer's sales for delivery within the state to total sales. UNIFord Division-OF Income For TAX PURPoses ACT \$\$ 9-17; Pierce, The Uniform Division of Income for State Tax Purposes, 35 Taxes 747 (1957).

203. See text at notes 69-75 supra.

204. For examples of such rates, suggested for use by commercial appraisers, see E. H. Boecke \& Associates, Manual of Appraisals 330 (3d ed. 1947) (rates range from 2\%/4$3 \%$ on long-term leaseholds to $12 \%$ on outlying, cheaply constructed and slum properties); Nelson, Capitalization Rates, 26 Apprarsal J. 34, 37-39 (1958). 
tions establishing "value" as the basis of realty taxation, ${ }^{205}$ and long-standing custom in other jurisdictions, ${ }^{206}$ will probably make any noticeable departure from "true value" unpalatable to many courts. Thus reform legislation would run the risk of total invalidation. Even under permissive constitutions, misunderstanding and opposition might well result in detailed procedural provisions and policy directives being treated as merely advisory and not binding. ${ }^{207}$ Such a failure to recognize the abandonment of "true value" as the basic feature of reform legislation would, manifestly, defeat reform itself. Less drastically, the limitations in some state constitutions on permissible realty tax exemptions might stand in the way of many antiregressive and subsidy provisions. ${ }^{208}$ In sum, constitutional reform will often be a necessary prerequisite to assessment reform. ${ }^{209}$

\section{Separating Spending Controls from Assessment Policy}

A final realty tax reform would sever the state regulation of municipal taxing and borrowing powers from the determination of property values-a dissociation which can be achieved under any type of assessment statute. The emergence of the "normal market" doctrine during the 1930's illustrates the dangers inherent in limiting the authority to tax and borrow to a fixed percentage of assessed value. The impracticality of these limitations has been further demonstrated during inflationary periods when assessors, unwilling to exercise their discretion to increase assessments, have hampered the maintenance of local governmental services once tax-rate limits have been reached. In many localities where sales and income taxes have opened new sources of revenue to municipal governments, rate limits on realty taxation have simply become

205. See Mrss. Const. art. 4, $\S 112$; appendix at p. 386 infra.

206. In Vermont, for instance, the constitution makes no mention of "value," but real property has been taxed according to its value in money since 1820 . Vt. Laws 1820 , ch. 1 , $\S 1$ (now VT. STat. $\S \S 684,713,748$ (1947)). But even such a long tradition need not prevent a departure from abstract notions of "value." Cf. Clark v. City of Burlington, 101 Vt. 391, 143 Atl. 677 (1928).

207. Cf. Zangerle v. Evatt, 139 Ohia St. 563, 41 N.E.2d 369 (1942).

208. Such a limitation may be express, GA. Const. art. 7, $\$ 2-5404$, or implied, S.C. Const. art. 10, $\$ \$ 1,4$, Textile Hall Corp. v. Hill, 215 S.C. 262, 54 S.E.2d 809, 815 (1949).

209. The amendment would have to be explicit enough to prevent judicial misconstruction from avoiding a statute implementing the amendment, but broad enough to prevent courts from formulating their own extrastatutory, value-review standards. The amendment might read:

All real property not exempted by law shall be taxed according to standards specified by the legislature or an administrative agency designated by the legislature. These standards may establish such classifications and such differing techniques for assessing real property as shall seem to the legislature best suited to distributing tax burdens equitably. No court shall review any assessment in any manner or on any grounds not specified by statute. 
obsolete as means of checking local spending power. ${ }^{210}$ Whatever the locality, if spending control is felt desirable, ceilings on total disbursements rather than on the tax rate per dollar of assessment seem preferable. Several states now impose ceilings of this sort, which either are in explicit dollar amounts, as in Minnesota, ${ }^{211}$ or provide that total tax revenues in each year may not exceed those of the preceding year by more than a given percentage, as in Colorado. ${ }^{212}$ Current methods for adjusting spending ceilings upward are the local referendum, ${ }^{213}$ proving necessity or other good cause to a state administrative body, ${ }^{214}$ and action by the state legislature. ${ }^{215} \mathrm{~A}$ possible alternative approach would correlate municipal spending power and business cycles by adjusting disbursement levels in accordance with the cost-of-living index. ${ }^{210}$ Regardless of the device adopted, legislatures seeking to control expenditures should not do so by restricting tax rates.

\section{Concluston}

Real estate taxation has long suffered from the legislatures' abdication of their responsibilities to courts and administrators who manipulate empty statutory intonations on "value" in order to implement policies of their own selection. Assessment standards, once chosen, are unevenly applied, and judicial review is sporadic-conditions which work to the disadvantage of taxpayers and taxing authorities. Consequently, detailed statutes delineating the procedures as well as the goals of realty tax assessment should replace the present legislative pronouncements directing assessors to find "true value," "actual value," "cash value," or "market value." At the same time, limits on local spending should be divorced from municipal tax rates. In this way, the distribution of tax burdens could be democratically determined, assessors would be shorn of their present policy-making function, taxpayers could protect themselves against bias, and the necessity for realty tax litigation would be minimized.

Of course, vested interests which benefit from current assessment practices

210. Most laws limiting municipal taxation apply only to property taxation and invite the evasive substitution of alternative taxes. See, e.g., PA. Stat. ANn. tit. 53, \& 6851 (C) (Supp. 1957). A few tax-limit laws, however, realistically cover revenues from all sources. See, e.g., N.Y. Const. art. $8, \S 10$.

211. Minn. Stat. Ann. $\$ 8275.09(3), .12$ (Supp. 1957).

212. See Colo. Rev. Stat. Ann. \$ 137-6-43 (1954).

213. See, e.g., Ark. Const. art. 9, § 2; Ohio Rev. Code ANn. \$§ 5705.07, 26 (Page 1954).

214. See, e.g., Ind. Stat. ANn. $\$ \$ 64-309,-311,-314$ (1951).

215. Such a course is possible wherever rate limits are statutory rather than constitutional. See, e.g., Mrnn. Const. art. 11, § 5; Mrnn. Stat. ANN. \$§ 275.31, .33-.48 (1947), 275.32 (Supp. 1957).

216. MrnN. Stat. ANN. $\$ \S 275.11, .12$ (Supp. 1957) (county tax limits increased for each point by which Consumer Price Index exceeds 102; school board limits for each point above 119). 
may be able to frustrate whatever popular sentiment exists for reform. Recent judicial decisions in New Jersey and Connecticut indicate, however, that, by refusing to undertake piecemeal a review of assessment irregularities, the courts may at least quicken the pace of legislative reform. In Switz $v$. Middletoren, for example, the Supreme Court of New Jersey ordered town officials to reassess all parcels at "full value" within three years. ${ }^{217}$ Through this sweeping order, the court sought to remand the question of chronic underassessment to the legislature. ${ }^{218}$ Faced with this order overturning decades of administrative custom and having serious implications for every county in New Jersey, ${ }^{219}$ the legislature has debated assessment reform at length and may soon codify the average, state-wide assessment level at forty per cent of market price as determined from comparative sales. ${ }^{220}$

A more prompt legislative response followed the Connecticut case of $E$. Ingraham Co.v. Bristol, in which the Supreme Court of Errors made known its intention to enforce the statutory "full value" provision strictly. ${ }^{221}$ The Connecticut legislature thereupon passed legislation substituting assessment at a

217. 23 N.J. 580,130 A.2d 15 (1957).

218. Id. at $598,130 \mathrm{~A} .2 \mathrm{~d}$ at 25 .

219. New Jersey assessors have traditionally assessed at less than computed value, although "true value" assessment has long been required by statute and, prior to 1947 , by the New Jersey constitution. N.J. Const. art. 4, $\$ 7(12)$ (1875); N.J. Stat. Ann. $\$ 54: 4-23$ (Supp. 1957). New Jersey courts have not only condoned the administrative policy of underassessment but also refused to reduce the assessments of relatively overassessed taxpayers. Instead, the courts have insisted that aggrieved taxpayers seek redress by utilizing administrative procedures for bringing assessments of other taxpayers up to full value. Royal $\mathrm{Mfg}$. Co. v. Board of Equalization of Taxes, 76 N.J.L. 402,70 Ati. 978 (Sup. Ct. 1908), aff'd, 78 N.J.L. 337, 74 Atl. 525 (Ct. Err. \& App. 1909). In Township of Hillsborough v. Cromwell, 326 U.S. 620 (1946), the Supreme Court held that, since the administrative procedures were so cumbersome as effectively to deny a grossly overassessed taxpayer a remedy, the policy of the New Jersey courts violated due process of law under the fourteenth amendment. In 1947, the year after the Hillsborough decision, New Jersey revised its constitution, omitting the full value requirement. N.J. Const. art. $8, \S 1$. Nevertheless, the taxing statute continued to require uniform assessment at "full and fair value." N.J. STAт. ANN. \& 54:4-23 (Supp. 1957). The courts responded to the revised constitution and the Hillsborongh case by reversing the Royal doctrine and, in Baldwin Construction Co. v. Essex County Bd. of Taxation, 16 N.J. 329, 108 A.2d 598 (1954), by reducing a contested assessment to the prevailing level. But the conflict between the statute requiring full value assessment and the constitutional uniformity edict remained to plague the judicial conscience of the late Chief Justice Vanderbilt. See id. at 346, 108 A.2d at 607 (dissenting opinion); Gibraltar Corrugated Paper Co. v. Township of North Bergen, 20 N.J. 213, 223, 119 A.2d 135, 140 (1955) (concurring opinion); Delaware, L. \& W.R.R. v. Neeld, 23 N.J. 561, 575, 130 A.2d 6, 14 (1957) (concurring opinion). The decision in Swits, requiring administrative compliance with both uniformity and full value provisions, was the logical outgrowth of this development, though the stay in carrying out the required revaluation once again drew protest from the Chief Justice. Switz v. Middletown Township, 23 N.J. 580, 618, 130 A.2d 15, 35 (1957) (dissenting opinion).

220. N.Y. Times, Sept. 14, 1958, $\$$ (Real Estate), p. 1, col. 7.

221. 144 Conn. 374, 132 A.2d 563 (1957). 
locally determined rate for assessment at "full value."222 Like the proposed New Jersey statute, the Connecticut act avoids rather than solves basic property tax policy issues. Hopefully, judicial persistence in revealing the inadequacies of contemporary legislation will eventually produce more constructive results.

222. Conn. Public Acts 1957, No. 673, at 1090. This statute had the effect of codifying the status quo in most localities. Except in a few areas, uniform underassessment had been the officially acknowledged practice under the "full value" statute. See [1954] Cown. Tax Comm'r, Informatton Relative to the Assessment and Collection of Taxes $35-43$ (1.955). 


\begin{tabular}{|c|c|c|c|c|c|c|c|c|c|c|c|c|c|c|c|c|c|c|c|c|}
\hline Alabaina & c & & & & & & $\mathbf{s}$ & s & & & & & & & & & & & $\operatorname{sos} \theta$ & 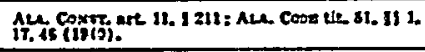 \\
\hline Arizona & & $\mathbf{s}$ & & & & & & $\mathbf{s}$ & & & & & & & & & & & 100 & 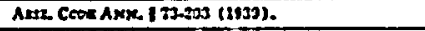 \\
\hline Arikansas & $\mathbf{c}$ & & & $\mathbf{s}$ & & & $\mathbf{s}$ & $\mathbf{s}$ & & & & & & & & & $\mathbf{c}$ & 8 & & 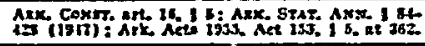 \\
\hline Cesliforais & $\mathbf{c}$ & $\mathbf{s}$ & & & & & & & $\mathbf{8}$ & & & & & & & & c & & 100 & 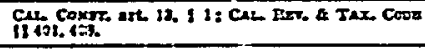 \\
\hline Colorado & & $\mathbf{s}$ & c & & & & $\mathbf{s}$ & $\mathbf{s}$ & & & s & & s & & 5 & & $\mathbf{c}$ & & & 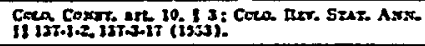 \\
\hline Conneeticut & & & . & $\mathbf{s}$ & s & & $\mathbf{s}$ & $\mathbf{s}$ & & & & & & & & & & & $\begin{array}{l}b x+1 \\
0 \infty \\
i \infty \infty\end{array}$ & 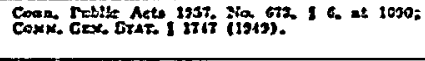 \\
\hline Delaware & & & & $\mathbf{s}$ & & & & & & & & & & & & & & & & 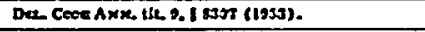 \\
\hline Florida . & & $\mathbf{s}$ & $\mathbf{c}$ & & & & & & & & & & & & & & c & & & 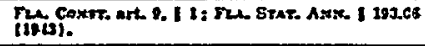 \\
\hline Georxis & & & s & & & $\mathbf{s}$ & $\mathbf{s}$ & $\mathbf{s}$ & & & & & & & & & & & & 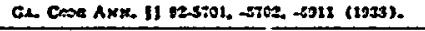 \\
\hline Ilabso & & $\mathbf{s}$ & & & & & & $\mathbf{s}$ & s) & $\mathbf{8}$ & & & s & & & & & & & 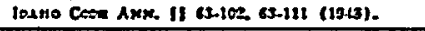 \\
\hline Illinois & $\mathrm{c}$ & & & & & & & $\mathbf{s}$ & & & & & & & & & C & & & 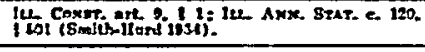 \\
\hline Indiann & & & s & $\mathbf{s}$ & & & & & & $\mathbf{s}$ & $\mathbf{s}$ & & & $\mathbf{I}$ & s- & & & & & 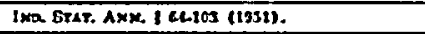 \\
\hline Towa & & & & - & $\mathbf{s}$ & & $\mathbf{s}$ & & & $\mathbf{s}$ & & & & 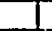 & $\mathbf{s}$ & & & & $\omega$ & $\operatorname{ton} 2 \cos A \times x, 1(12.13(1)(3)$. \\
\hline Kinness & & & & $\mathbf{s}$ & & & & $\mathbf{s}$ & & & & & & & & & & & & 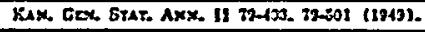 \\
\hline Kentucky & & & & & . & CS & & cs & & & & & & & & & & & & 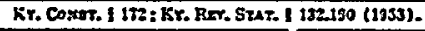 \\
\hline Louisiztz & & & & & $\mathrm{CS}$ & & & & & & & & & 2 & 5 & & c & & & 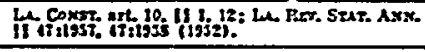 \\
\hline Maine & & & c| & & & & & & & & & & & & & & & & & 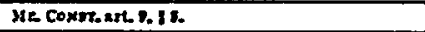 \\
\hline Marsiand & & $\mathbf{s}$ & & & & & & & & & & & & \pm & & & & & & Ha $\cos A x X_{0}$ art 11.131 (Sapd. 195z). \\
\hline stessachurets & & & & & & $\mathbf{s}$ & & & & & & & & & & & & & & 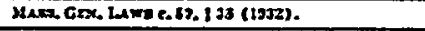 \\
\hline Mîchizan & cs: & & & & & & & $\mathbf{s}$ & & & & $\mathbf{s}$ & & 4 & & & & & & 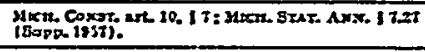 \\
\hline Slinnesota & & $\mathbf{s}$ & $\mathbf{s}$ & & & $\mathbf{s}$ & & $\mathbf{s}$ & & & & 81 & & 2 & 8 & $\mathbf{5}$ & & & & 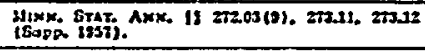 \\
\hline Mississippi & $\mathbf{c}$ & & & cs & & & & $\mathbf{s}$ & & & & s & & & $\mathbf{s}$ & & & & & 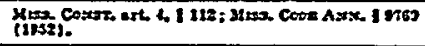 \\
\hline MSissouri & $\mathbf{c}$ & & & s & & & & & & & & & & & & & & & Lis & 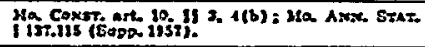 \\
\hline Montana & & & c & & & & & & s & & & & & & & & $\mathbf{c}$ & & $\begin{array}{c}\text { nart } \\
\infty\end{array}$ & 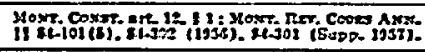 \\
\hline Nebraska & $\mathbf{c}$ & & & & $\mathbf{s}$ & & $\mathbf{s}$ & $\mathbf{s}$ & & $\mathbf{s}$ & s) & s & $\mathbf{s}$ & 2 & & & & & कs & 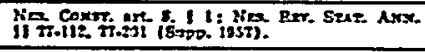 \\
\hline Nerzds & & s & $\mathbf{c}$ & & & & & & 8 & & & & & 5 & & $\mathbf{c}$ & & & & 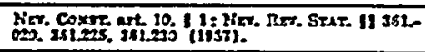 \\
\hline New Ilem nshinc & & $\mathbf{s}$ & & $\mathbf{s}$ & & & & & 8 & & & & & & 8 & & & & & SAL RTr. 874T. AxM. I 73:1 (1333). \\
\hline Nex Jersers & & $\mathbf{s}$ & & & & $\mathbf{s}$ & & $\mathbf{s}$ & & & & & & & & & & & & 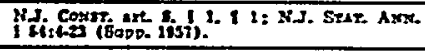 \\
\hline Nex Mexico & cs & & & & & & $\mathbf{s}^{\circ}$ & $\mathbf{s}^{*}$ & & & & & & 60 & & & & & & 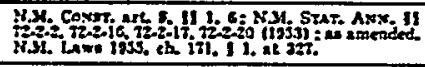 \\
\hline New York & & $\mathbf{c s}$ & & & & & & & & & & & & & & & & & & 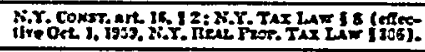 \\
\hline North Carolina & $\mathbf{s}$ & & & $\mathbf{s}$ & $s$ & & s & $\mathbf{s}$ & & & & & & & & & & & & 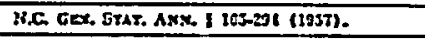 \\
\hline North Bakotz & & $\mathbf{s}$ & & $\mathbf{s}$ & & & & $\mathbf{s}$ & & & & & & & & & & & $\infty$ & 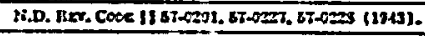 \\
\hline Ohlo & & $\mathbf{s}$ & & c & & & & $\mathbf{s}$ & & & & & & & & & & 8 & & 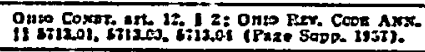 \\
\hline Oklahoms & & & & & & $\cos$ & & cS & & & & & & & & & & & & 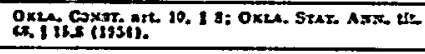 \\
\hline Oreson & & & & $\mathbf{s}$ & & & ser & so.. & & $\mathbf{s}$ & & s) & $\mathbf{s}$ & c.t & & & & 8 & & 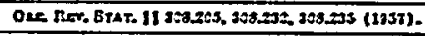 \\
\hline Peansylvaria & & & & & $\mathbf{s}$ & & $\mathbf{s}$ & $\mathbf{s}$ & & & & & & 2 & & & & & & 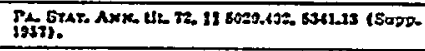 \\
\hline Fhode Ielend & & $\mathbf{s}$ & & & & $\mathbf{s}$ & & & & & & & & & & & c & & & 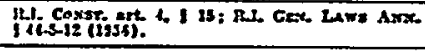 \\
\hline South Caroling & & & $\mathbf{c}$ & $\mathbf{s}$ & & & & & & & & & & $T$ & & & & & & 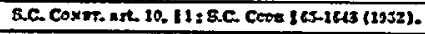 \\
\hline Sorth Dakols & & $\mathbf{s}$ & & $\mathbf{s}$ & & & & $\mathbf{s}$ & & & & & & & & 8 & & & & R.D. Cesa i (12.0131 (1933). \\
\hline Teanessere & c & & & & $\mathbf{s}$ & & & $\mathbf{s}$ & & St & & 81 & & & 81 & & c & & & 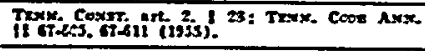 \\
\hline Tezas & $\mathbf{G}$ & $\mathbf{s}$ & & $\mathbf{s}$ & & c & c & $\mathbf{s}$ & & & & & & & & 8 & c & & & 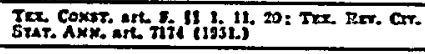 \\
\hline Utsh & $\mathbf{c}$ & & C & & & & & & $\mathbf{s}$ & & & & & & & & c & & 10 & 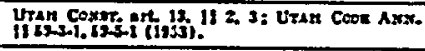 \\
\hline Vermont & & $\therefore$ & $\mathbf{s}$ & & & & & & & & & & & & & & & & & 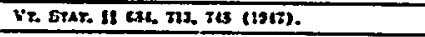 \\
\hline VIrrinin & & & & & & & cs & & & & & & & & & & o & & & 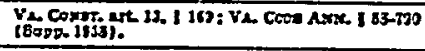 \\
\hline Preshinglon & & & & $\mathbf{s}$ & & $\mathbf{s}$ & & $s$ & $\mathbf{s}$ & & & & & & & $\mathbf{B}$ & & 8 & $\infty$ & 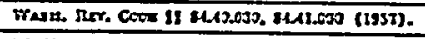 \\
\hline Wost Virsinia & $\mathbf{c}$ & & & $\mathbf{s}$ & $\mathbf{s}$ & & & $s$ & & stt & & & & & & & c & & & 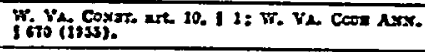 \\
\hline Wisconsin & & & & & & & & 5 & & & & 8 & & 1 & & & & & & Yta star. ( 70.12 (1) (125s). \\
\hline Wromian & & & $\mathbf{c}$ & & & $\mathbf{s}$ & & & & & & & & & & & c & 8 & & 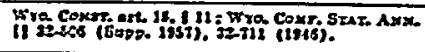 \\
\hline
\end{tabular}


